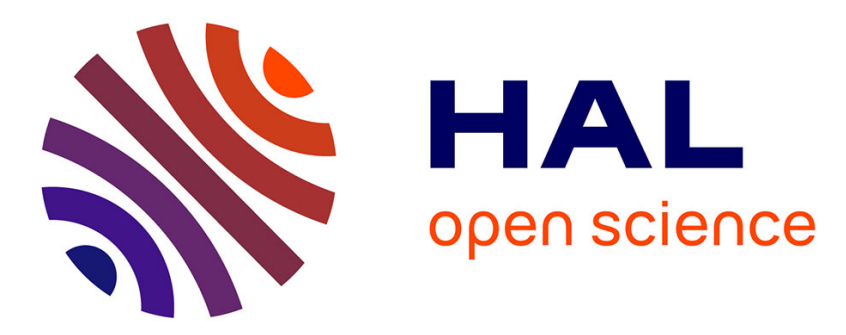

\title{
Internal Devaluations and Equilibrium Exchange Rates: new evidences and perspectives for the EMU
}

\author{
Jamel Saadaoui
}

\section{To cite this version:}

Jamel Saadaoui. Internal Devaluations and Equilibrium Exchange Rates: new evidences and perspectives for the EMU. Applied Economics, 2018, 50 (59), pp.6364-6381. 10.1080/00036846.2018.1486019 . hal-02168395v3

\section{HAL Id: hal-02168395 \\ https://hal.science/hal-02168395v3}

Submitted on 19 Apr 2023

HAL is a multi-disciplinary open access archive for the deposit and dissemination of scientific research documents, whether they are published or not. The documents may come from teaching and research institutions in France or abroad, or from public or private research centers.
L'archive ouverte pluridisciplinaire HAL, est destinée au dépôt et à la diffusion de documents scientifiques de niveau recherche, publiés ou non, émanant des établissements d'enseignement et de recherche français ou étrangers, des laboratoires publics ou privés. 


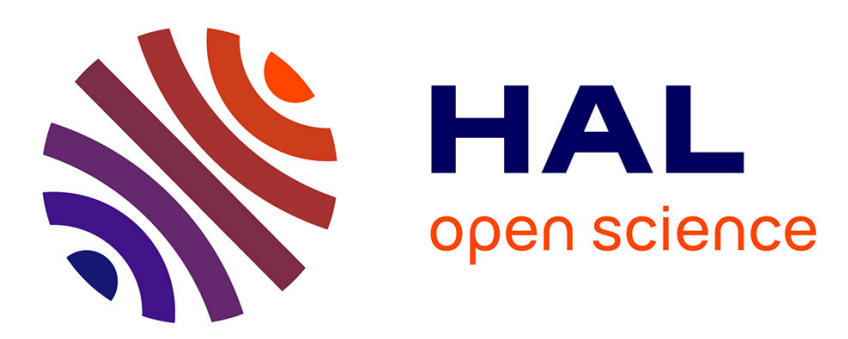

\title{
Internal Devaluations and Equilibrium Exchange Rates: New Evidences and Perspectives for the EMU
}

\author{
Jamel Saadaoui
}

\section{To cite this version:}

Jamel Saadaoui. Internal Devaluations and Equilibrium Exchange Rates: New Evidences and Perspectives for the EMU. 2017. halshs-01633389v2

\section{HAL Id: halshs-01633389 \\ https://shs.hal.science/halshs-01633389v2}

Preprint submitted on 12 Nov 2017

HAL is a multi-disciplinary open access archive for the deposit and dissemination of scientific research documents, whether they are published or not. The documents may come from teaching and research institutions in France or abroad, or from public or private research centers.
L'archive ouverte pluridisciplinaire HAL, est destinée au dépôt et à la diffusion de documents scientifiques de niveau recherche, publiés ou non, émanant des établissements d'enseignement et de recherche français ou étrangers, des laboratoires publics ou privés. 


\title{
INTERNAL DEVALUATIONS AND EQUILIBRIUM EXCHANGE RATES: NEW EVIDENCES AND PERSPECTIVES FOR THE EMU
}

\author{
Jamel Saadaoui ${ }^{\mathrm{a}}$ \\ ${ }^{a}$ University of Strasbourg, BETA-CNRS, CEPN-CNRS.
}

\author{
ARTICLE HISTORY \\ Compiled November 11, 2017
}

\begin{abstract}
From the onset of the euro crisis to the Brexit vote, we have witnessed impressive reductions of current account imbalances in peripheral countries of the euro area. These reductions can be the result of either a compression of internal demand or an improvement in external competitiveness. In this paper, we compute exchange rate misalignments within the euro area to assess whether peripheral countries have managed to improve their external competitiveness. After controlling for the reduction of business cycle synchronization within the EMU, we find that peripheral countries have managed to reduce their exchange rate misalignments thanks to internal devaluations. To some extent, these favourable evolutions reflect improvements in external competitiveness. Nevertheless, these gains could only be temporary if peripheral countries do not improve their non-price competitiveness, their trade structures and their international specializations in the long run.
\end{abstract}

\begin{abstract}
Abbreviations: EMU, European Monetary Union; FEER, Fundamental Equilibrium Exchange Rate; SMIM, Symmetric Matrix Inversion Method; BEER, Behavioural Equilibrium Exchange Rate; PPP, Purchasing Parity Power; OCI, Own Country Included; IMF, International Monetary Fund; OECD, Organisation for Economic Co-operation and Development; NIESR, National Institute of Economic and Social Research.
\end{abstract}

\section{KEYWORDS}

Internal Devaluation, Equilibrium Exchange Rate, External Competitiveness.

\section{JEL CLASSIFICATION}

F31, F32, F44, F45.

\section{Introduction}

From the onset of the euro crisis to the Brexit vote, we have witnessed impressive reductions of current account imbalances in peripheral countries of the euro area. As we can see in figure 1, Greece and Portugal have moved from current account deficits above ten percent of GDP in 2009 to virtually no imbalance in 2015. We observe a similar evolution for Italy and Spain, these countries respectively ran current account deficits of around 2 and 4 percent of GDP in 2009. Six years later, they run current account surpluses of around 2 percent of GDP. 
There is no denying that these evolutions have been partially due to compressions of internal demand following the onset of the euro crisis in these countries. Nevertheless, we can argue that these evolutions also reflect improvement in external competitiveness. In order to disentangle these different effects (internal demand or external competitiveness), we investigate the evolution of exchange rate misalignments within the euro area. Indeed, exchange rate misalignments (i.e. the difference between observed and equilibrium rates) have known contrasted evolutions during the euro crisis.

Using a two-step analysis, Jeong et al. (2010a) have shown that, in spite of no evidence of exchange rate misalignments for the euro as a whole, the euro area was affected by an increasing divergence during the 2000s in terms of exchange rates misalignments for several Member States ${ }^{1}$. This divergence of respective positions in terms of external competitiveness has been one of the main underlying drivers of the euro crisis. Thus, understanding whether peripheral countries have managed to improve their competitiveness or not seems to be especially important.

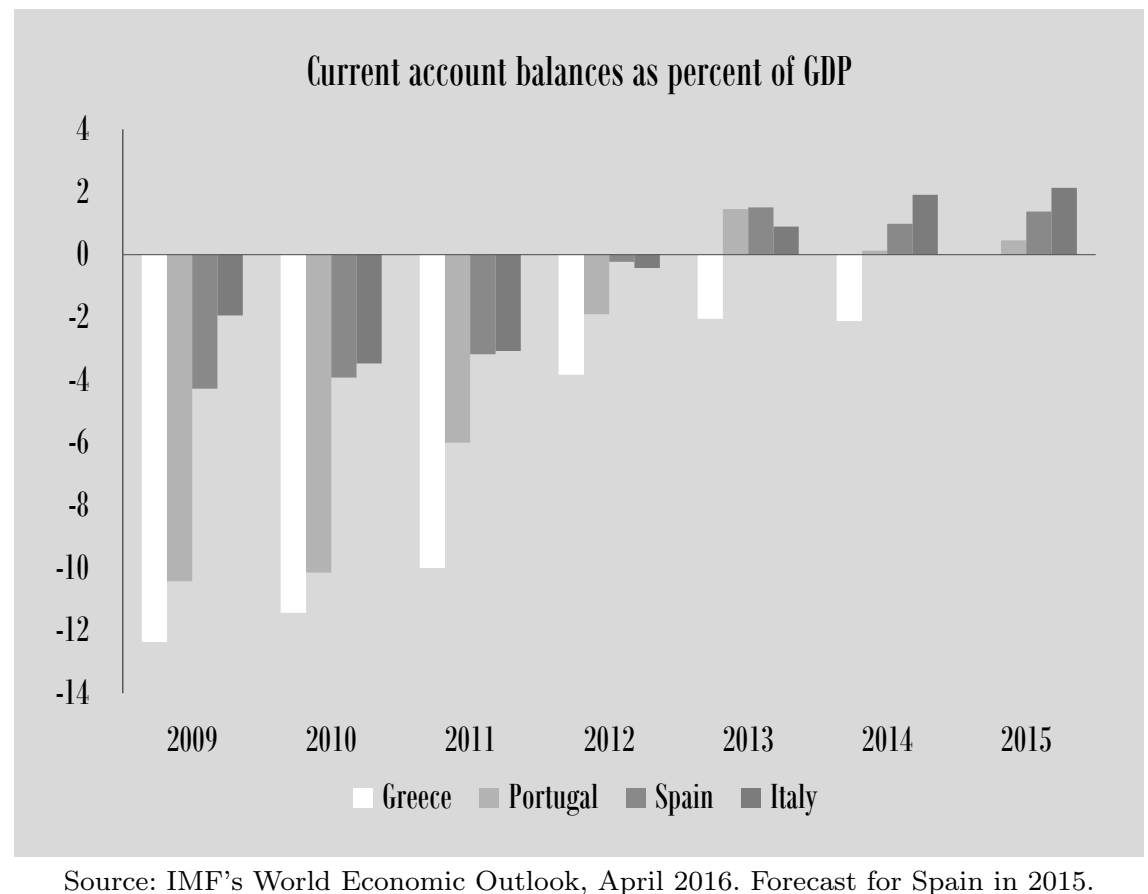

Figure 1. Current account balances as percent of GDP

In order to offset the effect of less synchronized business cycles ${ }^{2}$ in the euro area on the observed current account balances, we include the correction of Isard and Faruqee (1998) in the approach of Jeong et al. (2010a). Indeed, if a country grows below its relative potential (i.e. relative to that of its trading partners), it will generate current account surpluses or it will reduce its current account deficits. However, when the country closes its relative output gap, the movement will be reversed since the induced imports will increase. In this case, the reduction of the current account deficits will not have been due to an improvement in external competitiveness but rather to an

\footnotetext{
${ }^{1}$ Tridico and Fadda (2015) provide empirical evidences robust to structural breaks supporting the divergence of exchange rate misalignments within the euro area.

${ }^{2}$ Campos and Macchiarelli (2016) propose a new methodology to assess the degree of "coreness" of a country for members and non-members of the euro area. They show that divergence between core and periphery has been reinforced in recent years.
} 
output gap relatively inferior to that of its trading partners.

After ensuring these cyclical components of the current account have been corrected, we will be able to assess whether these reductions in the current account deficits reflect reduction of exchange rate misalignments or not within the euro area. Thus, the Fundamental Equilibrium Exchange Rate (FEER) approach ${ }^{3}$, pioneered by Williamson $(1983,1994)$, seems to be naturally suited to investigate this phenomenon. In recent years, other approaches have been used to explore this question of intra-European exchange rate misalignments like the BEER approach implemented by Coudert et al. (2013). They also detect that misalignments are quite heterogeneous in the euro area. However, the BEER approach assumes that misalignments are stationary (as they are residuals of co-integration relationships in this approach) over the studied period and seems to concern a long-run horizon as shown by López-Villavicencio et al. (2012). As we want to investigate a possible reduction in divergence of misalignments in the medium run, the FEER approach appears to be relevant ${ }^{4}$.

Our results confirm that exchange rate misalignments have been reduced in several peripheral countries. These reductions are partially caused by improvements in external competitiveness. However, we can observe that the euro has been largely undervalued in recent years (hereafter, the recent years refer to the period spanning from 2009 to 2016). This undervaluation of the euro can be simply explained by the fact that overvaluations in several peripheral countries have been reduced but undervaluations in the core have been quite stable.

To our knowledge, our study is the first one to investigate the evolution of exchange rate misalignments after controlling for the reduction of business cycle synchronization within the euro area over the period spanning from the onset of the euro crisis to the Brexit vote. Our new results could be especially important for policy-makers and academics since they might help to provide new perspectives about the most efficient (the less painful) way to improve external competitiveness in the EMU.

The remainder of this paper is organized as follows: firstly, we present the FEER methodology used to obtain exchange rate misalignments. Secondly, we focus on the results for the euro area and for several economies belonging to the monetary union over the period spanning from 1994 to 2016. Finally, we shed some light on the complex links between internal devaluations and external competitiveness.

\section{The FEER-SMIM methodology}

In order to compute exchange rate misalignments for the euro and within the monetary union, we use a two-step analysis based on the previous works of Borowski and Couharde (2003) and Jeong and Mazier (2003). In a first step, we use a multinational trade model for the main currencies (namely the U.S. dollar, the euro, the Chinese yuan, the Japanese yen and the pound sterling) and the Rest of the World. It is wellknown that this kind of modelling suffers from an over-determination problem. Indeed, as we have more equations (i.e. current account targets) than unknowns (i.e. independent bilateral exchange rates), several solutions are possible. In order to overcome this problem, we choose the solution offered by Cline (2008) to produce consistent equilibrium exchange rates. His parsimonious approach performs quite well in terms of

\footnotetext{
${ }^{3}$ The FEER approach aims at estimating an exchange rate consistent with the internal equilibrium and the external equilibrium in the medium run.

${ }^{4}$ The BEER and the PPP approaches are more relevant to investigate issues and questions that concern a longer temporal horizon as indicated in Driver and Westaway (2005).
} 
meeting the ex-post targets ${ }^{5}$ as shown by Carton and Hervé (2012).

The OCI (i.e. Own Country Included) solution of Cline (2008) consists in successively solving the model in which each country plays the role of the Rest of World ${ }^{6}$. In our case, we have 6 different resolutions in which each country successively plays the role of the Rest of the World. Here, the OCI solution consists in averaging the five resolutions that contain the current account target of the country. Indeed, for each economy, we average the results of five resolutions (out of six) in which its current account target is included in the model. This methodology allows obtaining consistent equilibrium exchange rates at the global level.

In a second step, we use a national trade model in order to obtain exchange rate misalignments within the euro area for several Member States. Jeong and Mazier (2003) show that the national trade model gives very similar results to those obtained for relatively small countries in a multinational set-up at the global level.

\subsection{The multinational trade model}

In the following, we present the multinational model used to describe the trade structure of the leading currencies in the global economy, namely the U.S. dollar, the euro, the Japanese yen, the Chinese yuan and the pound sterling. We use standard specifications that describe trade volumes (equations 1 and 2) and trade prices (equations 5 and 6 ). For the residual country, the trade volumes are obtained through equations that ensure the world trade is balanced in volume and in value (equations 3 and 4) ${ }^{7}$. We can note that the real effective exchange rate (equation 8) is computed by using consumer prices (equation 7). Finally, the current account for the residual country is not included but can be derived from the current account of the other trading partners (equation 9).

In order to complete this brief presentation of the multinational model, we define the different variables involved in equations 1 to $9: X$, represents the non-oil exports in volume; $D I$, is the internal demand; $C O M P X$, is an indicator of external pricecompetitiveness; $P X$ and $P M X$, are, respectively, export prices and competitors' export prices; $M$, represents the non-oil imports in volume; $P M$ and $P M M$, are import prices and competitors' import prices, respectively; $P D$, is the consumer price index; $P$, the GDP deflator; $E$, is the nominal exchange rate vis-à-vis the U.S. dollar; $R$, represents the real effective exchange rate based on consumer prices; $B$, is the current account balance in value; $i$, is the interest rate for external debt; $F$, the net external debt; Ppet, is the oil price and Mpet, the net oil imports.

For the sake of clarity, we also define several parameters involved in the multinational trade model: $\eta x$ and $\varepsilon x$, represent, respectively, income and price elasticities of exports; $\eta m$ and $\varepsilon m$, are, respectively, income and price elasticities of imports; $\alpha x$ and $\alpha m$ are parameters that capture, respectively, the price taking behaviour of exporting / importing firms; the parameter $a$ captures the intensity of the exchange rate passthrough. Finally, we can note that the trade shares involved the computations, $\lambda, \mu, \nu$ and $\alpha$ are detailed in appendix A.

\footnotetext{
${ }^{5}$ As there are more ex-ante current account targets than independent bilateral exchange rates, the ex-post targets are slightly different from the ex-ante targets.

${ }^{6}$ For the $n^{\text {th }}$ country, the current account target is not reached.

${ }^{7}$ Since, at the global level, the world economy does not run any trade imbalance against itself.
} 


\section{Foreign trade volume equations}

Export volume equation

$$
\begin{aligned}
X_{i} & =X_{0 i} D M_{i}^{\eta x_{i}} C O M P X^{\varepsilon x_{i}} \\
D M_{i} & =\prod_{j \neq i} M_{j}^{\alpha_{i j}} \\
C O M P X_{i} & =\left(\frac{P M X_{i}}{P X_{i}}\right)
\end{aligned}
$$

Import volume equation

$$
M_{i}=M_{0 i} D I_{i}^{\eta m_{i}}\left(\frac{P D_{i}}{P M_{i}}\right)^{\varepsilon m_{i}}
$$

Where $i$, is one of the five main trading partners amongst the six countries or aggregates (namely the U.S., the euro area, Japan, China, the U.K. and the Rest of the World) used in each model resolution. For the purpose of clarity, we can take the example of the asymmetric approach of Jeong and Mazier (2003). In this case, the Rest of the World is the residual country, thus $i$ is the one of five main trading partners (namely the U.S., the euro area, Japan, China and the U.K.). In our case, we follow the symmetric approach based on Cline (2008). Each trading partner is successively treated as the residual one in the six resolutions of the model.

\section{World trade consistency}

Consistency in value

$$
\sum_{i} \frac{P X_{i} X_{i}}{E_{i}}=\sum_{i} \frac{P M_{i} M_{i}}{E_{i}}
$$

Consistency in volume

$$
\sum_{i} X_{i}=\sum_{i} M_{i}
$$

Where $i$, is one of the six countries or aggregates (namely the U.S., the euro area, Japan, China, the U.K. and the Rest of the World) used in each model resolution.

\section{Price equations}

Export price equation

$$
\begin{aligned}
P X_{i} & =P M X_{i}^{\alpha x_{i}} P_{i}^{1-\alpha x_{i}} \\
P M X_{i} & =\prod_{j \neq i}\left(\frac{E_{i} P X_{j}}{E_{j}}\right)^{\lambda_{i j}}
\end{aligned}
$$


Import price equation

$$
\begin{aligned}
P M_{i} & =P M M_{i}^{\alpha m_{i}} P D_{i}^{1-\alpha m_{i}} \\
P M M_{i} & =\prod_{j \neq i}\left(\frac{E_{i} P X_{j}}{E_{j}}\right)^{\mu_{i j}}
\end{aligned}
$$

Consumer price equation

$$
P D_{i}=P M_{i}^{a_{i}} P_{i}^{1-a_{i}}
$$

Real effective exchange rates

$$
R_{i}=\prod_{j \neq i}\left(\frac{\left(\frac{P D_{j}}{E_{j}}\right)^{\nu_{i j}}}{\left(\frac{P D_{i}}{E_{i}}\right)}\right)
$$

Where $i$, is one of the six countries or aggregates (namely the U.S., the euro area, Japan, China, the U.K. and the Rest of the World) used in each model resolution.

\section{Current account balance}

Current account

$$
\begin{aligned}
B_{i} & =P X_{i} X_{i}-P M_{i} M_{i}-E_{i} P_{\text {pet }} M_{\text {pet }_{i}}-i_{i} E_{i} F_{i} \\
B_{\text {res }} & =-\sum_{i=1}^{5} B_{i}
\end{aligned}
$$

Where $i$, is one of the five main trading partners amongst the six countries or aggregates (namely the U.S., the euro area, Japan, China, the U.K. and the Rest of the World) used in each model resolution.

In order to compute the exchange rate misalignments directly, the model is written in logarithmic differential (see appendix A). In the following, variables with a lower case will correspond to logarithmic differences. For example, the exchange rate misalignment in nominal bilateral terms will be equal to $e=\frac{d E}{E}=\frac{d E-E^{*}}{E^{*}}$ where $E^{*}$ is the Fundamental Equilibrium Exchange Rate (i.e. the FEER). We can underline that the current account gap will be computed as a simple difference, thus $b=\frac{B}{P Y}-\frac{B^{*}}{P Y^{*}}$ where $\frac{B^{*}}{P Y^{*}}$ represents the current account target obtained thanks to panel econometric techniques as in Lee et al. (2008). In this context, the FEER of an economy is the level of exchange rate consistent with the simultaneous elimination of the current account gap and of the output gap. It allows the realization of the internal and external equilibrium in a consistent multinational framework.

Overall, each multinational model involves 35 endogenous variables $(x, m, p x, p m, p d$ for the six countries or aggregates and five bilateral nominal exchange rates, $e$, since the U.S. dollar is the numeraire currency) for 35 equations $(x, m, b$ for five countries other than the residual one; $p d, p x, p m$ for the six countries or aggregates and two equations to ensure world trade consistency). 
Table 1. Structure of the multinational model ${ }^{\mathrm{a}}$

\begin{tabular}{ll}
\hline Endogenous variables & Equations \\
\hline$x_{i}(1$ to 5$)$ & $x_{i}(1$ to 5$)$ \\
$m_{i}(1$ to 5$)$ & $m_{i}(1$ to 5$)$ \\
$x_{6}$ & $\sum_{i} x i=\sum_{i} m_{i}$ \\
$m_{6}(1$ to 6$)$ & $\sum_{i} p x_{i} x_{i}-e_{i}=\sum_{i} p m_{i} m_{i}-e_{i}$ \\
$p x_{i}(1$ to 6$)$ \\
$p m_{i}(1$ to 6$)$ & $p m_{i}(1$ to 6$)$ \\
$p d_{i}(1$ to 6$)$ & $p d_{i}(1$ to 6$)$ \\
$e_{i}(1$ to 5$)$ & $b_{i}(1$ to 5$)$ \\
\hline$r_{i}(1$ to 5$)$ & $r_{i}(1$ to 5$)$ \\
\hline$r_{6}$ & $r_{6}$ \\
\hline $\mathbf{3 5}+\mathbf{5}+\mathbf{1}$ endogenous variables & $\mathbf{3 5}+\mathbf{5}+\mathbf{1}$ equations \\
\hline
\end{tabular}

a Notes: lower case variables indicate variables transformed in logarithmic differences except for the current account balance. In the FEER-SMIM approach, each country or aggregate is successively treated as a residual country. The real effective exchange rates are calculated ex post using bilateral exchange rates and consumer prices. In the approach of Jeong and Mazier (2003), for the residual country (i.e. the sixth country), the exchange rate misalignment is consistent with that of its trading partners but not with its current account target.

As we can see in table 1, the residual country has an exchange rate misalignment consistent with the other trading partners but its current account gap is not contained within the calculations. The OCI (Own Country Included) solution consists in averaging all the solutions in which its current account gap is included. For each country or aggregate, we average the solution of five models (out of six solutions) in which its current account gap is included, thus ensuring a symmetric treatment.

\subsection{The national trade model}

In a first step, we use the aforementioned multinational trade model in order to compute exchange rate misalignments for the euro area as a whole. In a second step, we use a national trade model in order to obtain exchange rate misalignments for several Member States within the euro area. Thanks to this two-step analysis, we can derive an equilibrium exchange rate for and/or within the euro area. In the national model, world demand and trade prices are exogenous since we analyse relatively small countries at the global level.

In the following equations, we describe the trade volumes (equations 10 and 11) and trade prices (equations 12 and 13) for a relatively small country facing the world economy. The current account balance, for several Member States, is described in equation 14 . We can note that real effective exchange rates are defined relatively to the GDP deflator (equation 15). Finally, as mentioned before, world prices are exogenous in the national trade model (equation 16).

In order to complete this brief presentation of the national model, we define the different variables involved in equations 10 to 16: $X$, represents the non-oil exports in volume; $D^{*}$, is the (exogenous) world demand in volume; $P^{*}$ and $P X$, are, respectively, world prices and export prices; $M$, represents the non-oil imports in volume; $D I$, is the internal demand in volume; $P M$ and $P$, are, respectively, import prices and the GDP deflator; $E$ is the nominal exchange rate vis-à-vis the U.S. dollar; $R$, represents the real effective exchange rate based on the GDP deflator; $B$, is the current account balance in value; $i$, is the interest rate for external debt; $F$, the net external debt; 
Ppet, is the oil price and Mpet, the net oil imports.

For the sake of clarity, we also define several parameters involved in the national trade model: $\eta x$ and $\varepsilon x$, represent, respectively, income and price elasticities of exports; $\eta m$ and $\varepsilon m$, are, respectively, income and price elasticities of imports; $\alpha x$ and $\alpha m$ are parameters that capture, respectively, the price taking behaviour of exporter firms / importer firms. Finally, we can note that the trade shares involved the computations, $\lambda$ and $\mu$ are detailed in appendix A.

$$
\begin{gathered}
X_{i}=X_{0 i} D_{i}^{* \eta x_{i}}\left(\frac{E_{i} P_{i}^{*}}{P X_{i}}\right)^{\varepsilon x_{i}}=X_{0 i} D_{i}^{* \eta x_{i}} R_{i}^{\left(1-\alpha x_{i}\right) \varepsilon x_{i}} \\
M_{i}=M_{0 i} D I_{i}^{\eta m_{i}}\left(\frac{P_{i}}{P M_{i}}\right)^{\varepsilon m_{i}}=M_{0 i} D I^{\eta m_{i}} R_{i}^{-\alpha m_{i} \varepsilon m_{i}} \\
P X_{i}=\left(E_{i} P_{i}^{*}\right)^{\alpha x_{i}} P_{i}^{1-\alpha x_{i}}=R_{i}^{\alpha x i} P_{i} \\
P M_{i}=\left(E_{i} P_{i}^{*}\right)^{\alpha m_{i}} P_{i}^{1-\alpha m_{i}}=R_{i}^{\alpha m i} P_{i} \\
B_{i}=P X_{i} X_{i}-P M_{i} M_{i}-E_{i} P_{p e t} M_{p e t_{i}}-i_{i} E_{i} F_{i} \\
P_{i}^{*}=P X_{i}^{*}=\prod_{j \neq i}\left(\frac{P X_{j}}{E_{j}}\right)^{\lambda_{i j}} \cong P M_{i}^{*}=\prod_{j \neq i}\left(\frac{P X_{j}}{E_{j}}\right)^{\mu_{i j}} \\
R_{i}=\left(\frac{E_{i} P_{i}^{*}}{P_{i}}\right)
\end{gathered}
$$

Where $i$, is one of the eight Member States included in our investigation (namely France, Germany, Italy, Spain, Finland, Ireland, Portugal and Greece) and $j$, is one the six main trading partners of the multinational model (namely the U.S., the euro area, Japan, China, the U.K. and the Rest of the World $)^{8}$.

Same as for the multinational framework, we solve this national trade model in logarithmic differential in order to directly compute exchange rate misalignments for several Member States (see appendix B). Thus, the following equations describe the misalignment specific to each economy within the euro area. Indeed, the exchange rate misalignment can be expressed in real effective terms based on the GDP deflator

${ }^{8}$ For the sake of precision, we underline that we use the OCI solution for the multinational trade prices included in the national trade model. 
(equation 17), in real effective terms based on consumer prices (equation 18) and in bilateral nominal terms (equation 19).

$$
\begin{gathered}
r_{i}=\left[\frac{\left(\left(b_{i} / \mu_{i} T_{i}\left(1-\sigma p e t x_{i}-\sigma x_{i}\right)\right)+\eta m_{i} d i_{i}-\eta x_{i} d_{i}^{*}\right)}{\left(\left(1-\alpha x_{i}\right) \varepsilon x_{i}+\varepsilon m_{i} \alpha m_{i}+\alpha x_{i}-\alpha m_{i}\right)}\right] \\
r c_{i}=\left(1-\alpha m_{i} \mu_{i}\right) r_{i}+\sum_{j \neq i} \nu_{i j}\left(p d_{j}-e_{j}\right)-\sum_{j \neq i} \lambda_{i j}\left(p x_{j}-e_{j}\right) \\
e_{i}=r_{i}-\sum_{j \neq i} \lambda_{i j}\left(p x_{j}-e_{j}\right)
\end{gathered}
$$

As underlined by Saadaoui (2015b), the exchange rate misalignment depends on three exogenous variables ${ }^{9}$, namely: $b$, the current account gap (i.e. the difference between the actual current account balance and the so-called underlying capital flows); $d i$, the internal demand gap (i.e. the difference between the actual internal demand and the internal demand that would ensure a non-inflationary potential); and $d^{*}$, the foreign demand gap (i.e. the difference between the actual foreign demand and the foreign demand that would ensure a non-inflationary potential for trading partners).

The trade elasticities used in both the multinational and the national model can be found in Jeong et al. (2010b). They are very close to those obtained in the OECD international trade model (Pain et al., 2005). The structure of our models is very similar to that used in international institutions like the IMF, the OECD or the NIESR. Moreover, the specifications used in our trade models ensure that sensitivity to a peculiar parameter is quite limited (Jeong et al., 2010a).

The underlying capital flows have been estimated thanks to panel econometric techniques following the approach of Lee et al. (2008). It consists in using medium to long run determinants of the current accounts balances ${ }^{10}$ in order to determine an equilibrium/structural current account balance. This equilibrium current account balance is meant to be financed (or to finance in case of a structural surplus) by the rest of the world through underlying capital flows. Thus, we assume that a non-negligible part of capital flows is not aimed at financing long run growth prospects. Consequently, the exchange rate should correct the difference between the total amount of capital flows and the underlying capital flows.

The exact econometric specifications of the current account regressions are fully exposed in Jeong et al. (2010a) ${ }^{11}$. In appendix C, we present the results in terms of current account projections for the main five trading partners in the multinational trade model (namely the U.S., the euro area, Japan, China and the U.K.) over the period spanning from 1994 to 2016.

\footnotetext{
${ }^{9}$ For the purpose of clarity, we can also note that $\sigma p e t x=E P_{p e t} M_{p e t} / P X X$ is the ratio of net oil imports in value on non-oil exports in value and that $\sigma x=i E F / P X X$ is the ratio of the foreign debt service on non-oil exports in value.

${ }^{10}$ Such as the structure of net foreign assets, relative demographic ratios/relative population growth and relative productivity rates.

${ }^{11}$ Note that Saadaoui (2015a) finds very similar results when we extend the current account regressions to the crisis period and that the inclusion of a de jure or de facto variable of financial openness does not change the results qualitatively.
} 


\subsection{The Bayoumi-Faruqee correction}

In their previous calculations, Jeong et al. (2010a) do not correct the actual current account balance for a possible reduction in business cycles synchronization between several Member States within the euro area. Indeed, before the onset of the euro crisis, we could consider that business cycles in the euro area were quite synchronized. Consequently, there was no reason to expect large movements in current account balances caused by different positions in the business cycle during the 2000s.

Since the onset of the euro crisis, this assumption of relatively well synchronized business cycles is not valid any more. Campos and Macchiarelli (2016) propose a new time varying methodology to assess the "coreness" of a country based on the synchronization of demand/supply shocks coming from a VAR specification. They have shown that we have witnessed a decreasing synchronization of business cycles between the core and the periphery of the euro area. This reduced synchronization of business cycles is partially caused by the compression of aggregate demand observed in peripheral countries which have implemented internal devaluations.

Indeed, when a country has an output gap relatively weaker than that of its trading partners, it generates a current account surplus (or reduces its deficit). However, this improvement is not due to a better price or non-price external competitiveness but rather to a reduction of its induced imports. Eventually, when the country reaches its potential output, the current account deficit will increase (or the surplus will decrease) since the external competitiveness has not been improved.

Symmetrically, when a country has an output gap relatively higher than that of its trading partners, it generates a current account deficit (or reduces its surplus). As previously mentioned, this deterioration is not due to a worse price or non-price external competitiveness but rather to an increase of its induced imports. Eventually, when the country reaches its potential output, the current account surplus will increase (or the deficit will decrease) since the external competitiveness has not been deteriorated.

In order to consider the diminution of business cycle synchronization in the euro area, we have implemented the correction proposed by Tamim Bayoumi and Hamid Faruqee in Isard and Faruqee (1998). Thanks to this correction, we are able to determine whether the reductions of current account deficits observed in peripheral countries are mainly due to an improvement in external competitiveness (reflected in a reduction of exchange rate misalignments) or not.

This correction is based on a parsimonious model in which trade volume are related to real exchange rates. Besides, imports in volume depend on domestic output gap and exports in volume reacts to foreign output gap (i.e. a weighted average of trading partners' output gaps). In order to consider that exchange rate movements on the current account are not instantaneous, delayed effects of exchange rate variations are spread over three years (60\%, the first year; $25 \%$, the second and $15 \%$, the third). The real exchange rate does not influence the export price in domestic currency while it immediately and entirely affects the import price. We can write the current account balance in percentage of GDP as follows:

$$
\begin{aligned}
C A / Y=\alpha+\left[(M / Y) \beta_{m}+(X / Y) \beta_{x}\right]\left(0.6 R+0.25 R_{-1}+0.15 R_{-2}\right) \\
-(M / Y) R-(M / Y) \psi_{m} Y G A P+(X / Y) \psi_{x} Y G A P F
\end{aligned}
$$

Where $Y G A P F$, is the average output gap of the main partners; $R$, the logarithm of the real exchange rate (an increase of $R$ indicates a depreciation); $\beta_{x}, \beta_{m}$, the long 
run export and import price elasticities, respectively; $\psi_{x}, \psi_{m}$, long run export and import volume elasticities, respectively.

In case of real appreciation (a decrease of $R$ ), imports in volume increase while exports in volume decrease with lagged effects of the exchange rate variations but current account is improved thanks to cheaper imports. Lastly, a rising domestic output gap has a negative impact on current account while foreign output gap has an opposite effect.

The underlying current account $\left(C A / Y_{\text {und }}\right)$ is the current account corrected for the effects of past and present exchange rate variations and by the effects of the domestic and foreign output gaps:

$$
C A / Y_{\text {und }}=\alpha+\left[(M / Y) \beta_{m}+(X / Y) \beta_{x}\right] R-(M / Y) R
$$

Thanks to equations 20 and 21, we can obtain the Bayoumi-Faruqee correction to compute the underlying current account $\left(C A / Y_{\text {und }}\right)$ :

$$
\begin{aligned}
C A / Y_{\text {und }}=C A / Y+\left[(M / Y) \beta_{m}+\right. & \left.(X / Y) \beta_{x}\right]\left(0,4 \Delta R+0,15 \Delta R_{-1}\right) \\
& +(M / Y) \psi_{m} Y G A P-(X / Y) \psi_{x} Y G A P F
\end{aligned}
$$

In equation 22 , we can easily observe that a country with an output gap relatively weaker than that of its trading partners will have a lower underlying current account balance because when it closes its relative output gap (i.e. the difference between $Y G A P$ and $Y G A P F)$, its induced imports will increase. Symmetrically, a country with an output gap relatively stronger than that of its trading partners will have a higher underlying current account balance.

\section{Results}

\subsection{Misalignments for the euro area}

In a global perspective, the most striking feature of our results is that the euro area is now largely undervalued (see table 2). During the 2000s, the most undervalued trading partner was the Chinese economy. There is growing consensus that the yuan is no longer undervalued since its current account surplus has reduced from 10 to less than 2 percent of GDP between 2007 and 2014. Indeed, as shown in appendix C, the current account gap has been close to zero in recent years for the Chinese economy.

The undervaluation of the euro is not surprising since several peripheral countries of the euro area have reduced their overvaluations thanks to internal devaluations and some core countries of the euro area have preserved their misalignments since the onset of the crisis. In recent years, the current account gap of the euro area becomes largely positive thanks to the movements in the periphery. The current account balance has moved from around one-half to less than 3 percent of GDP between 2010 and 2014 . This value largely overshoots the current account target/underlying capital flows in the medium run.

During the second half of the 2000s, we have observed a clear opposition between an overvalued U.S. dollar and an undervalued Chinese yuan that has fuelled many political 
Table 2. Exchange rate misalignments in the multinational trade model ${ }^{\mathrm{a}}$

\begin{tabular}{|c|c|c|c|c|c|c|c|c|c|c|c|}
\hline & \multicolumn{5}{|c|}{ Nominal Bilateral } & \multicolumn{6}{|c|}{ Real Effective } \\
\hline & $e_{\text {row }}$ & $e_{c h}$ & $e_{e u}$ & $e_{j p}$ & $e_{u k}$ & $r_{\text {row }}$ & $r_{c h}$ & $r_{e u}$ & $r_{j p}$ & $r_{u k}$ & $r_{u s}$ \\
\hline 2004 & 17.8 & 20.6 & 20.8 & 20.9 & 10.3 & 4.9 & 6.0 & 7.2 & 8.2 & -5.5 & -21.9 \\
\hline 2005 & 25.0 & 30.3 & 20.7 & 25.0 & 16.8 & 9.4 & 11.0 & 1.9 & 7.8 & -1.7 & -29.1 \\
\hline 2006 & 24.6 & 36.7 & 20.5 & 26.5 & 15.6 & 8.7 & 16.7 & 1.6 & 8.5 & -2.9 & -31.0 \\
\hline 2007 & 10.2 & 29.3 & 8.1 & 17.2 & 7.0 & 3.8 & 20.7 & -0.2 & 9.0 & -0.4 & -20.7 \\
\hline 2008 & 14.4 & 31.5 & 12.4 & 15.6 & 5.8 & 3.5 & 17.6 & 0.9 & 2.5 & -6.0 & -18.9 \\
\hline 2009 & 13.7 & 21.6 & 17.6 & 9.4 & 1.4 & 0.6 & 6.4 & 6.6 & -4.6 & -13.0 & -11.1 \\
\hline 2010 & 14.2 & 21.0 & 16.9 & 19.3 & 4.8 & 0.5 & 4.5 & 4.9 & 4.7 & -9.6 & -11.7 \\
\hline 2011 & 18.8 & 14.4 & 23.1 & 13.2 & 6.4 & 3.1 & -3.4 & 8.6 & -2.3 & -11.9 & -12.9 \\
\hline 2012 & 11.9 & 10.5 & 25.8 & 10.3 & -0.6 & -1.7 & -2.6 & 16.3 & -1.0 & -17.2 & -9.9 \\
\hline 2013 & 8.9 & 6.9 & 26.0 & 14.2 & -2.5 & -4.7 & -5.9 & 18.0 & 3.4 & -18.6 & -5.4 \\
\hline 2014 & 6.0 & 6.5 & 25.8 & 8.3 & -6.2 & -6.1 & -3.7 & 20.1 & -0.4 & -21.0 & -4.0 \\
\hline 2015 & -4.3 & -1.1 & 23.9 & 5.7 & -10.9 & -9.0 & -0.6 & 26.1 & 7.0 & -19.4 & -4.9 \\
\hline 2016 & -4.6 & -1.8 & 26.1 & 4.9 & -11.5 & -9.2 & -0.6 & 28.6 & 7.0 & -20.8 & -6.8 \\
\hline
\end{tabular}

aNotes: In the multinational trade model, $e$ indicates exchange rate misalignments in nominal bilateral terms vis-à-vis the U.S. dollar and $r$ designates exchange rate misalignments in real effective terms based on consumer prices. Forecasts for 2016 are based on current account projections of the IMF's World Economic Outlook (April 2016).

tensions ${ }^{12}$. After the onset of the euro crisis and the reduction of global imbalances observed after the start of the Great Recession, it seems that the U.S. dollar and the Chinese yuan are no longer misaligned. This result is quite remarkable but since it has not been achieved by an international monetary cooperation, this reduction could be only temporary.

In spite of clear-cut reductions of exchange rate misalignments in the two biggest economies at the global level, exchange rate misalignments have not been uniformly reduced for the other trading partners of the multinational model (see figures 2 and 3 ). The pound sterling is now the most overvalued currency at the global level ${ }^{13}$. These evolutions reflect the growing divergence of the European economies rather than a more traditional opposition on trade issues like it was the case for the U.S. and China during the second part of the 2000s.

\subsection{Misalignments within the euro area}

\subsubsection{Business cycle synchronization within the euro area}

As underlined by Jeong et al. (2010a), the exchange rate misalignment for the euro area as a whole does not necessarily reflect the exchange rate misalignment for each individual Member State. Thus, it appears relevant to compute an equilibrium exchange rate for each Member State since large individual differences persist in terms of inflation, trade structure and international specialization.

We can clearly see in figures 4 to 6 that the domestic output gaps have been systematically lower than those of their trading partners for Italy, Spain, Portugal and

\footnotetext{
${ }^{12}$ Bergsten (2010) illustrates these political tensions due to the fact that undervaluations can be considered as an unfair advantage in terms of price-competitiveness in foreign markets (Blanchard and Milesi-Ferretti, 2012). An undervaluation of the domestic currency amounts to a combination of tariffs on imports cum subsidies on exports.

${ }^{13}$ Even if the British pound has known several depreciations since the onset of the euro crisis, the current account gap remains largely negative partially reflecting the fact that the British economy is highly opened to cross-border movements of capital flows. In 2015, the fair value of the British pound produced by our approach is 1.37 U.S. dollar per pound sterling. The same year, the actual value was 1.53 U.S. dollar per pound sterling.
} 

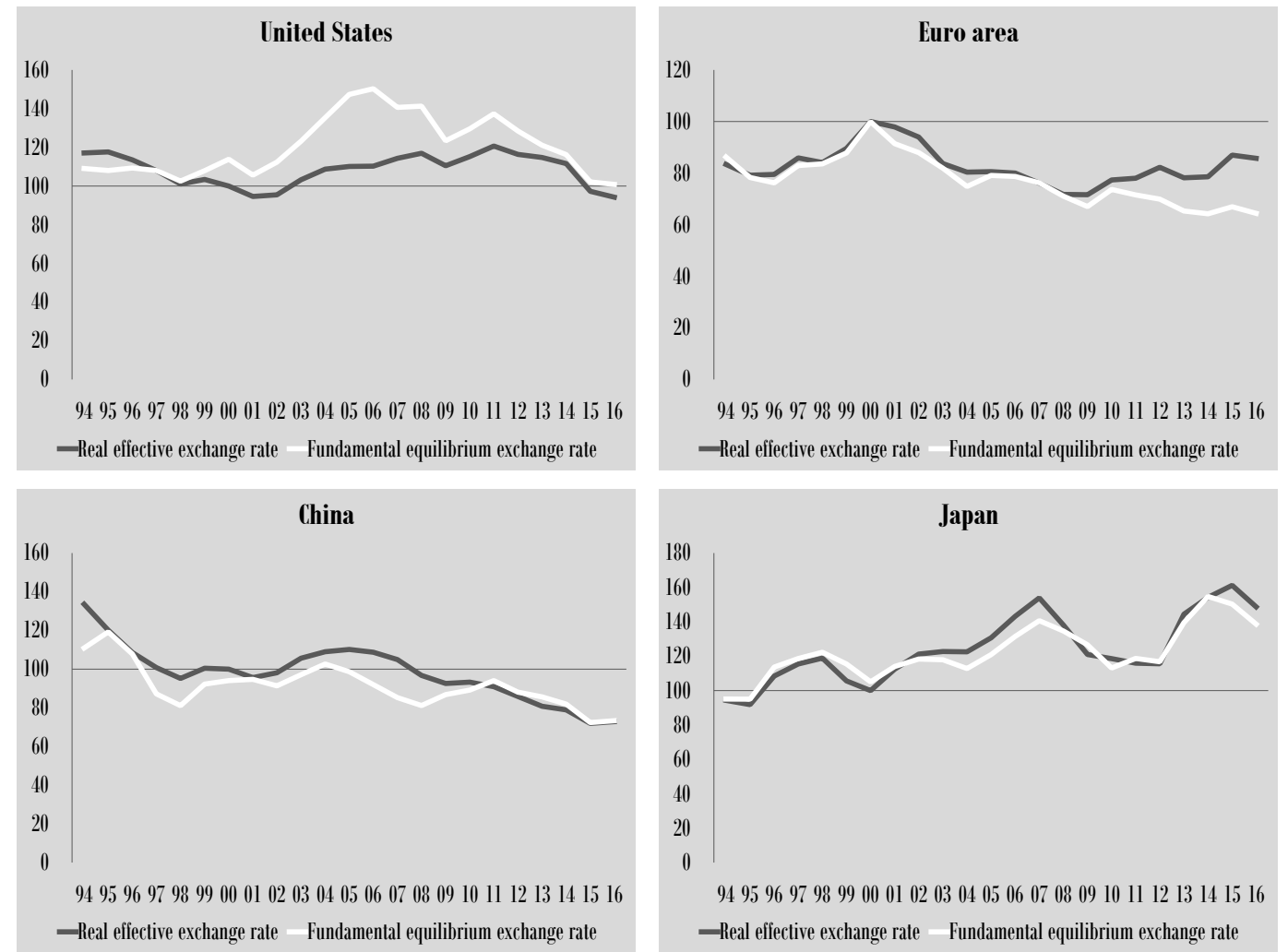

Source: author's calculations for the FEER and BIS, IFS, Bruegel for real effective exchange rates, basis 100 in 2000. Notes: An increase (decrease) of the real effective exchange rate corresponds to a depreciation (appreciation).

Figure 2. Actual and equilibrium real effective exchange rates 

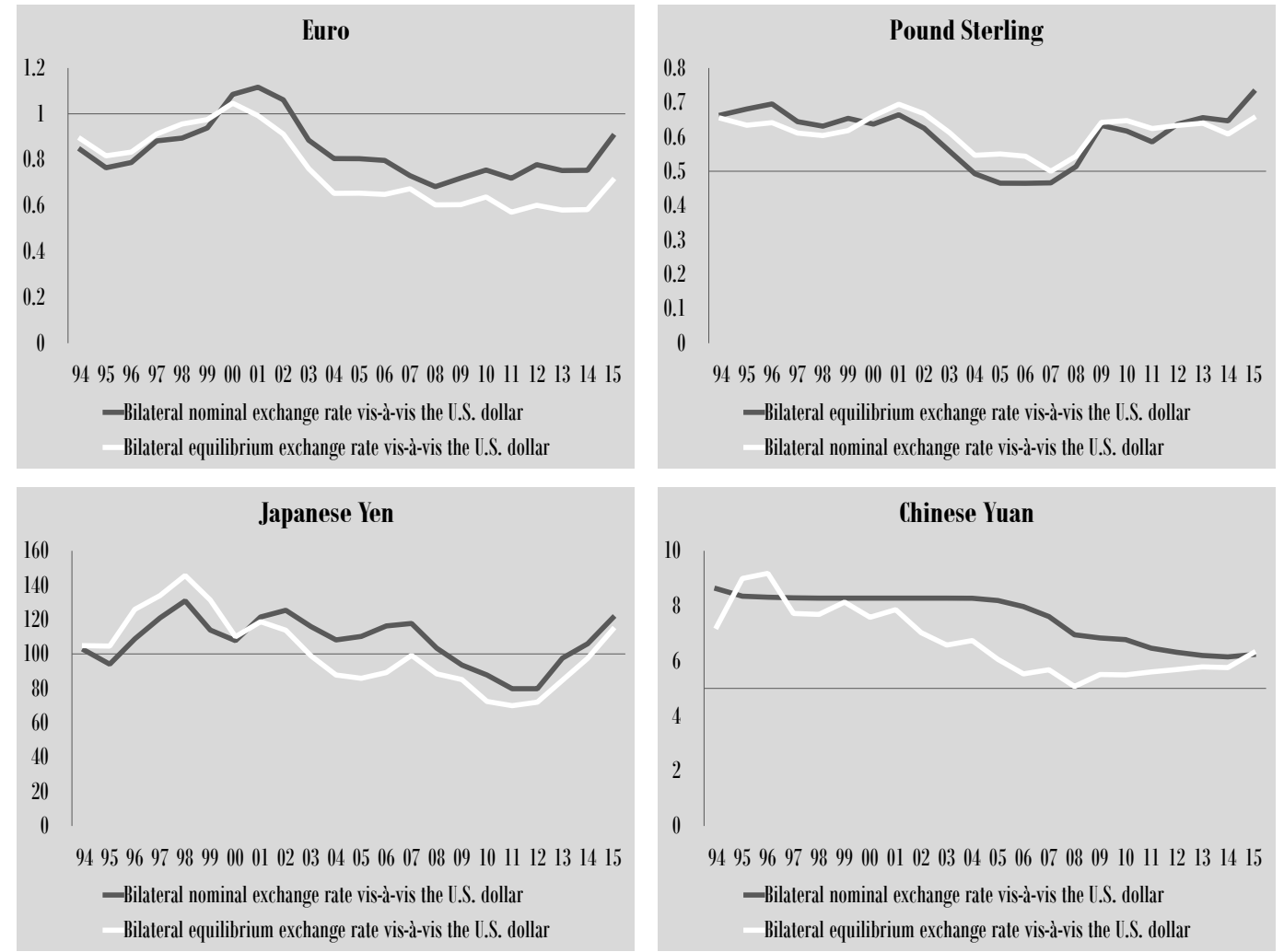

Source: author's calculations for the bilateral FEER and OECD for bilateral nominal exchange rates. Notes: An increase (decrease) of the bilateral nominal exchange rate corresponds to a depreciation (appreciation).

Figure 3. Actual and equilibrium real effective exchange rates (continued) 

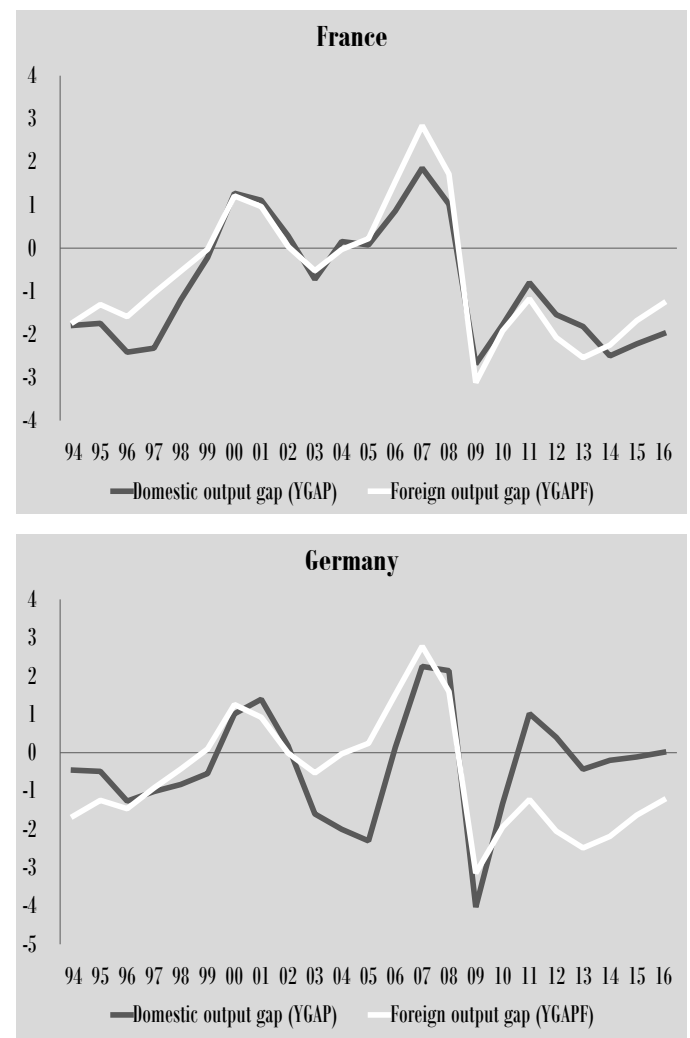

Italy

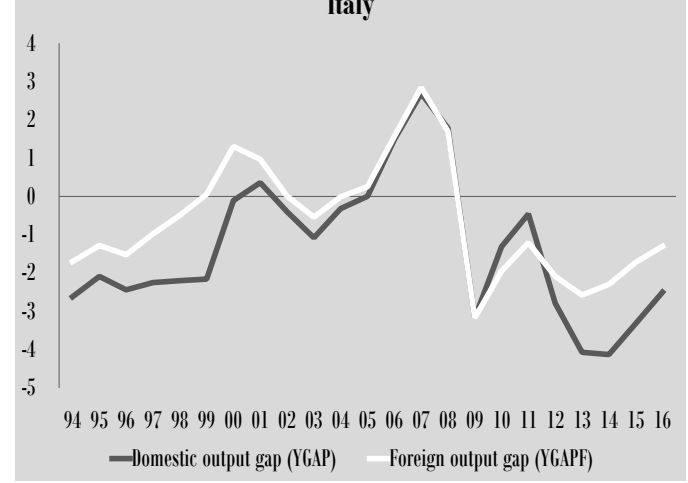

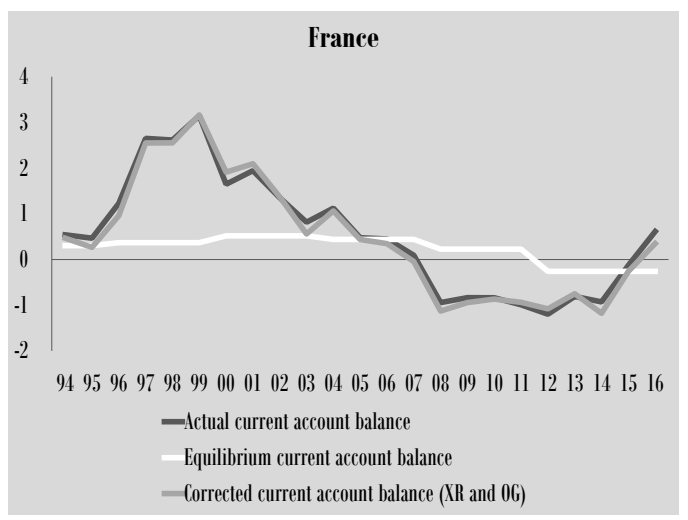

Germany

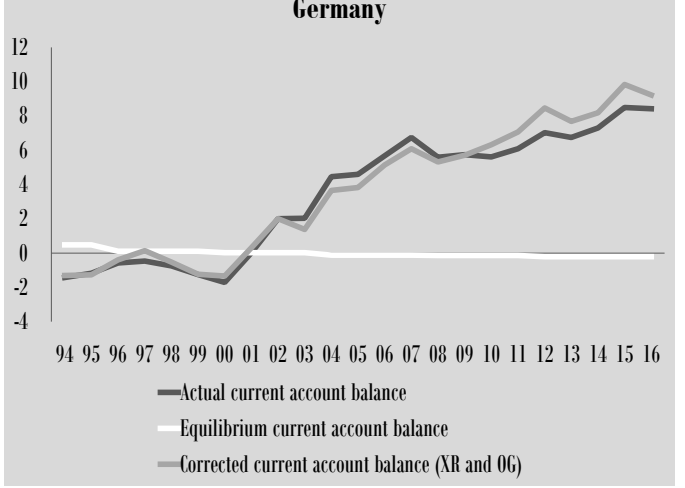

Italy

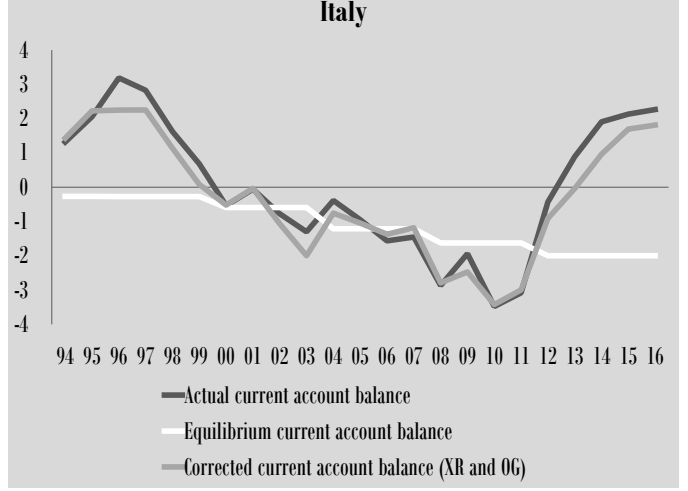

Source: author's estimates for the equilibrium current account balance and IMF for the output gap. Notes: the foreign output gap is a trade weighted average of foreign output gaps.

Figure 4. Relative output gaps and current account gaps 

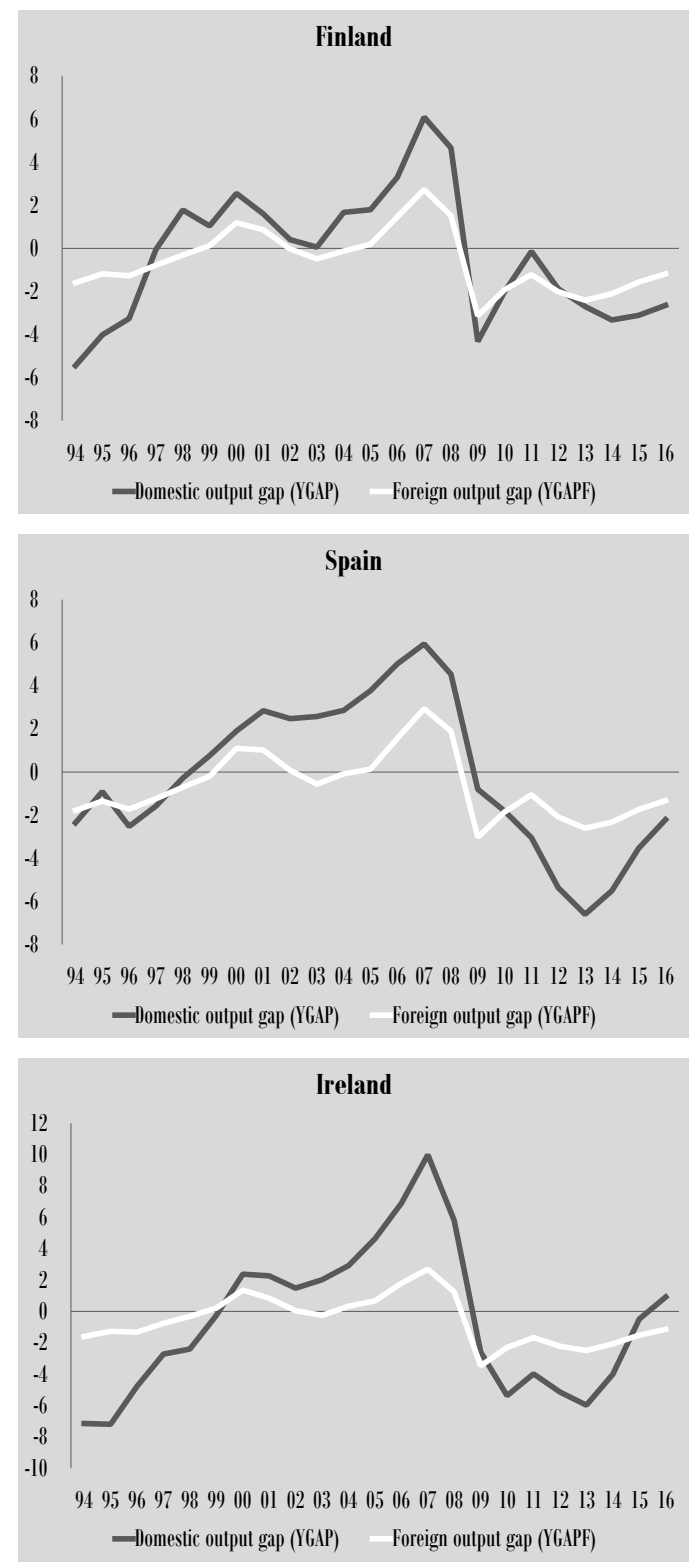
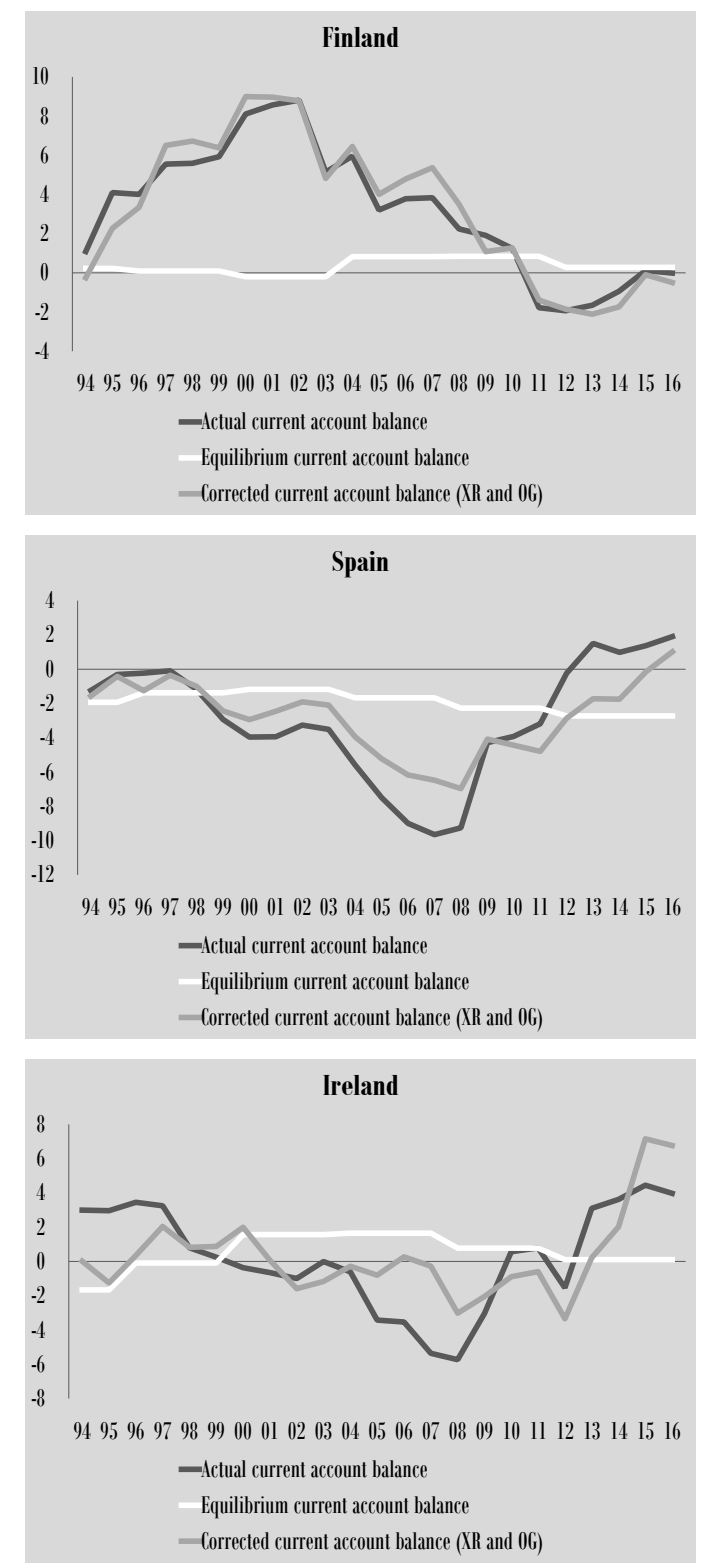

Source: author's estimates for the equilibrium current account balance and IMF for the output gap. Notes: the foreign output gap is a trade weighted average of foreign output gaps.

Figure 5. Relative output gaps and current account gaps (continued) 

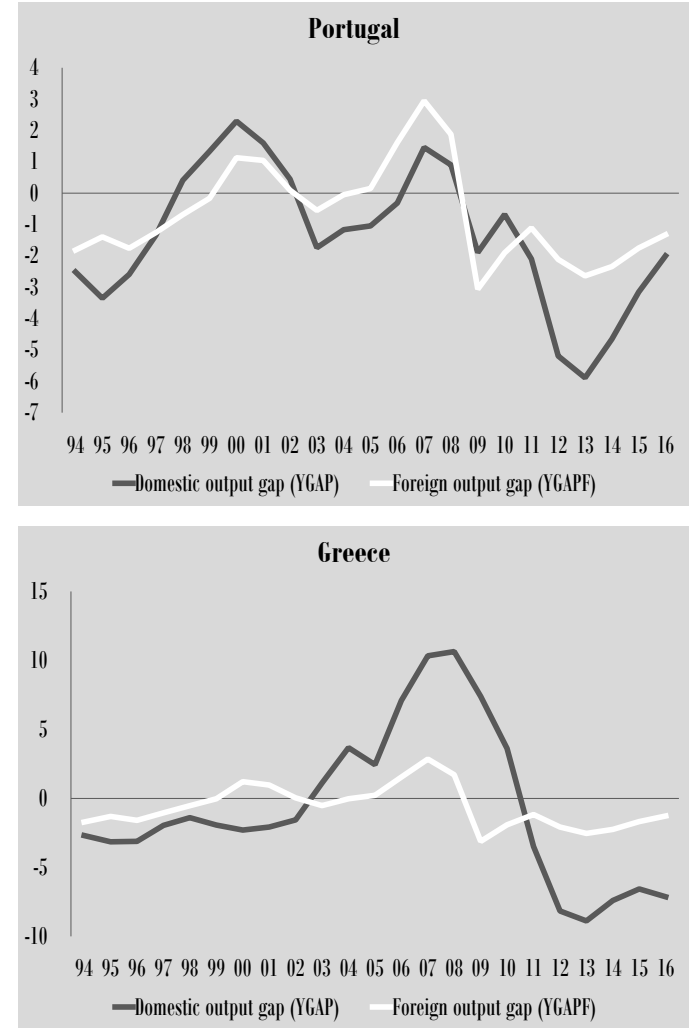

Portugal

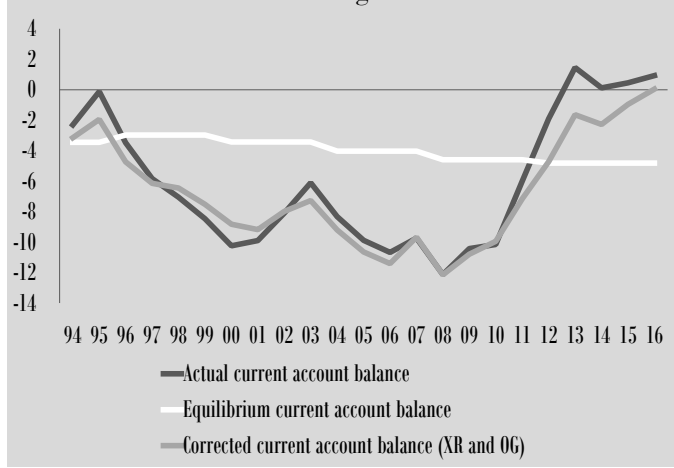

Greece

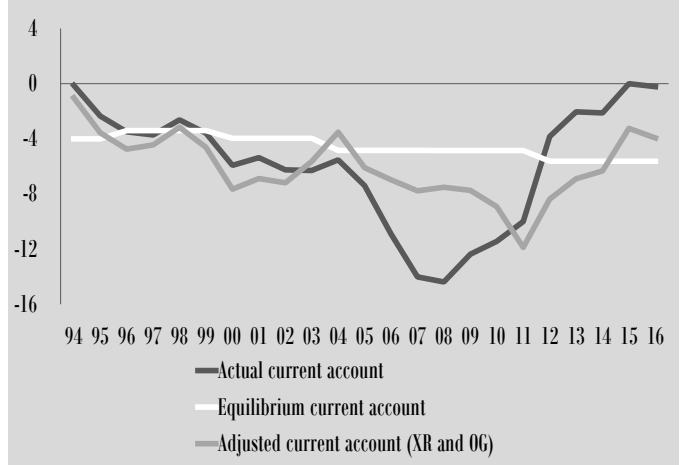

Source: author's estimates for the equilibrium current account balance and IMF for the output gap. Notes: the foreign output gap is a trade weighted average of foreign output gaps.

Figure 6. Relative output gaps and current account gaps (continued) 
Greece since the start of the euro crisis. This striking feature indicates that when these countries close their relative output gaps, they will experience a reduction of their current account surpluses or an increase of their current account deficits. In other words, it seems irrelevant to infer a priori that external competitiveness has been improved simply because actual current account deficits have been massively reduced during an economic slowdown in which aggregate demand is depressed.

On the other side, while France and Finland seemed to have balanced positions, we can observe, in figures 4 to 6 , that the domestic output gap has been higher than the foreign output gap in Germany and Ireland, in recent years. This means that the underlying current account balance is higher (than the actual one) in these countries since their trading partners will import more when they reach their potentials. We can note that Ireland has managed to switch from a negative relative output gap to a positive one since the start of the crisis. This evolution is partially due to the fact that the Irish economy is very open to external trade. As opposed to the Greek or the Portuguese economy, which are examples of small semi-closed economies, the Irish economy is particularly prone to reap the benefits of internal devaluations ${ }^{14}$.

\subsubsection{Reduction of misalignments within the euro area}

As we can see in tables 3 and 4 , the impressive reductions of current account imbalances observed since the onset of the crisis have been accompanied by reductions of exchange rate misalignments in Italy, Spain, Portugal and to a lesser extent in Greece. Overall, these countries have managed to improve their external competitiveness in order to reduce their current account deficits. In figures 8 to 9 , we can see that these evolutions are reflected in an appreciation of the Fundamental Equilibrium Exchange Rate (i.e. the FEER).

Indeed, when the FEER appreciates, the country is able to compete on foreign markets with higher prices in the case of a structural improvement of its competitiveness. Conversely, when the FEER depreciates, the country needs lower prices to be competitive on foreign markets in the case of a structural deterioration of its competitiveness. Nevertheless, if cyclical evolutions of external competitiveness driven by internal devaluations occurred, we may fear that these favourable evolutions will be offset in the case of a future appreciation of the euro in real effective terms ${ }^{15}$.

The Irish economy is very interesting since it could illustrate a case of structural improvement in external competitiveness. Indeed, the Irish economy has several features that are particularly useful to reap the benefits of internal devaluations. The Irish economy is very open to external trade, thus changes in relative prices affect a large part of its GDP. Besides, since its foreign market shares are more oriented towards the U.S., the Irish economy is more isolated to adverse evolutions in the euro area than other European countries like Greece or Portugal. We can argue that Ireland is an example of a very flexible/small open economy in which internal devaluations (i.e. reducing relative prices through compression of wages) could perhaps generate positive effects in the long run.

In spite of an improvement in external competitiveness in Italy, Spain, Portugal and to a lesser extent in Greece, reflected in a reduction of their misalignments, it

\footnotetext{
${ }^{14}$ Saadaoui et al. (2013) provide empirical evidences showing that trade openness is a non-linear determinant of exchange misalignments. Indeed, the more the country is open to trade, the less the exchange rate misalignment is large in absolute value.

${ }^{15}$ In this respect, Saadaoui (2011) offers an interesting distinction between structural improvement of competitiveness and cyclical improvement of competitiveness.
} 
Table 3. Real effective exchange rate misalignments within the euro area ${ }^{\mathrm{a}}$

\begin{tabular}{rrrrrrrrr}
\hline \multicolumn{7}{c}{ Real Effective } & \multicolumn{7}{c}{} \\
\hline & $r c_{\text {fra }}$ & $r c_{\text {ger }}$ & $r c_{\text {ita }}$ & $r c_{\text {spa }}$ & $r c_{f i n}$ & $r c_{\text {irl }}$ & $r c_{\text {prt }}$ & $r c_{\text {grc }}$ \\
\hline $\mathbf{2 0 0 4}$ & -0.1 & 5.6 & -5.4 & -15.4 & 19.6 & -3.8 & -40.1 & 5.0 \\
$\mathbf{2 0 0 5}$ & -4.6 & 5.3 & -4.1 & -20.3 & 7.8 & -4.8 & -46.1 & -7.6 \\
$\mathbf{2 0 0 6}$ & -4.8 & 9.1 & -3.8 & -24.6 & 9.7 & -2.0 & -47.9 & -6.3 \\
$\mathbf{2 0 0 7}$ & -6.0 & 13.1 & -0.7 & -26.4 & 15.5 & -0.9 & -34.5 & -5.2 \\
$\mathbf{2 0 0 8}$ & -13.3 & 13.0 & -4.5 & -33.3 & 11.7 & -4.7 & -46.3 & -3.7 \\
$\mathbf{2 0 0 9}$ & -8.3 & 13.9 & -2.9 & -10.2 & 0.2 & -0.7 & -34.4 & -8.5 \\
$\mathbf{2 0 1 0}$ & -6.9 & 16.8 & -4.2 & -14.6 & 2.5 & -0.9 & -28.1 & -21.1 \\
$\mathbf{2 0 1 1}$ & -10.1 & 16.8 & -5.8 & -22.9 & -5.9 & -2.5 & -19.6 & -53.1 \\
$\mathbf{2 0 1 2}$ & -12.6 & 19.3 & -2.5 & -14.1 & -8.9 & -7.9 & -12.2 & -30.9 \\
$\mathbf{2 0 1 3}$ & -5.0 & 18.7 & 1.5 & -3.6 & -7.2 & 1.4 & 6.8 & -20.3 \\
$\mathbf{2 0 1 4}$ & -10.1 & 19.4 & 3.8 & -2.7 & -7.4 & 5.9 & 4.4 & -15.4 \\
$\mathbf{2 0 1 5}$ & -8.2 & 18.7 & 2.4 & 6.1 & -6.7 & 12.8 & 8.6 & 1.9 \\
$\mathbf{2 0 1 6}$ & -5.2 & 15.8 & 2.0 & 14.3 & -8.6 & 11.7 & 14.1 & -5.2 \\
\hline
\end{tabular}

a Notes: In the national trade model, $r c$ designates exchange rate misalignments in real effective terms based on consumer prices. Forecasts for 2016 are based on current account projections of the IMF's World Economic Outlook (April 2016).

Table 4. Bilateral nominal exchange rate misalignments within the euro area $^{\mathrm{a}}$

\begin{tabular}{|c|c|c|c|c|c|c|c|c|}
\hline & \multicolumn{8}{|c|}{ Nominal Bilateral } \\
\hline & $e_{f r a}$ & $e_{g e r}$ & $e_{i t a}$ & $e_{s p a}$ & $e_{f i n}$ & $e_{i r l}$ & $e_{\text {prt }}$ & $e_{g r c}$ \\
\hline 2004 & 17.8 & 23.8 & 11.5 & -0.2 & 40.8 & 9.9 & -33.5 & 24.6 \\
\hline 2005 & 15.1 & 26.7 & 16.0 & -4.0 & 31.0 & 11.9 & -41.1 & 12.2 \\
\hline 2006 & 14.8 & 31.6 & 16.5 & -10.0 & 33.9 & 15.4 & -45.2 & 13.8 \\
\hline 2007 & 1.9 & 25.0 & 8.2 & -24.4 & 28.5 & 7.0 & -36.9 & 3.0 \\
\hline 2008 & -3.7 & 27.9 & 7.2 & -30.0 & 26.8 & 3.9 & -47.4 & 8.5 \\
\hline 2009 & 4.0 & 30.2 & 10.8 & 1.3 & 13.8 & 8.6 & -29.3 & 4.8 \\
\hline 2010 & 6.0 & 33.9 & 9.5 & -4.2 & 17.0 & 9.3 & -21.4 & -10.2 \\
\hline 2011 & 6.5 & 37.9 & 12.0 & -9.9 & 10.8 & 10.6 & -4.9 & -43.8 \\
\hline 2012 & 2.5 & 39.0 & 14.3 & 0.5 & 4.3 & 1.8 & 4.7 & -18.7 \\
\hline 2013 & 10.5 & 37.2 & 17.9 & 12.9 & 4.9 & 11.9 & 28.2 & -7.2 \\
\hline 2014 & 3.2 & 36.6 & 19.2 & 12.8 & 2.9 & 15.5 & 24.2 & -2.8 \\
\hline 2015 & 1.3 & 30.8 & 12.5 & 20.2 & -2.3 & 20.2 & 26.4 & 12.8 \\
\hline 2016 & 5.9 & 28.2 & 12.8 & 31.9 & -4.2 & 19.4 & 35.0 & 5.4 \\
\hline
\end{tabular}

a Notes: In the national trade model, $e$ indicates exchange rate misalignments in nominal bilateral terms vis-à-vis the U.S. dollar. Forecasts for 2016 are based on current account projections of the IMF's World Economic Outlook (April 2016).

seems quite questionable to explain that the economic structure of these countries is particularly suited to reap the benefits of internal devaluations. Indeed, these countries are quite close to external trade (especially the Greek and the Portuguese economy). Since their foreign market shares are more oriented towards the European Union, these economies are more vulnerable to adverse evolutions in the euro area. Thus, the improvement in external competitiveness (obtained thanks to internal devaluations) could only be temporary (cyclical) since these countries will not be able to change their trade structures or their international specializations in the short run.

As previously mentioned, the euro has been largely undervalued in recent years. This evolution is driven by the reduction of overvaluations in several peripheral countries like Italy, Spain, Portugal and Greece and by stable undervaluations in the main core country, namely Germany. Indeed, the euro has been undervalued by around twenty percent for the German economy since the onset the crisis. These evolutions are explained by large underlying current account surpluses (around eight percent in 

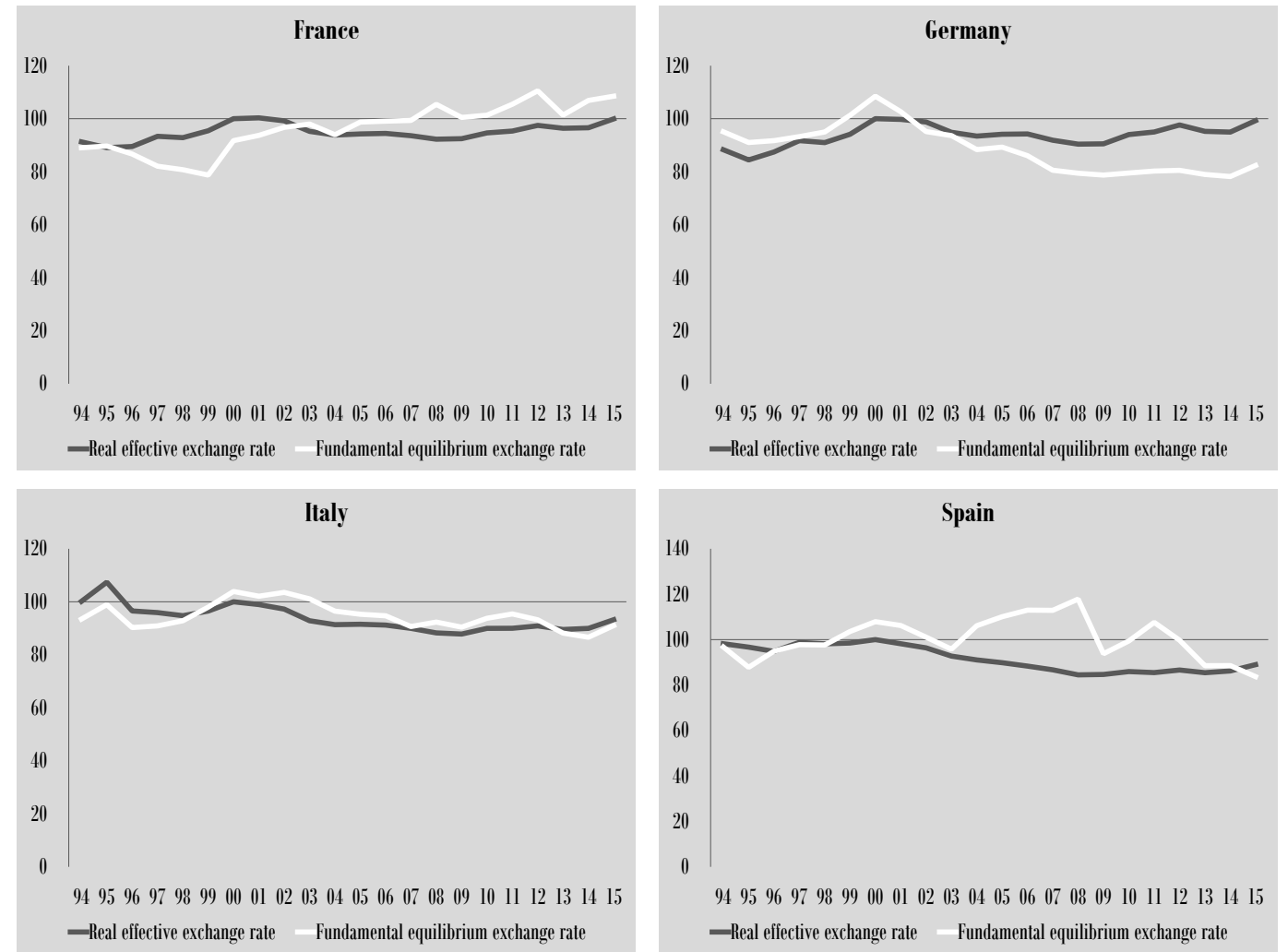

Source: author's calculations for the FEER and BIS for real effective exchange rates, basis 100 in 2000. Note: an increase (decrease) of the real effective exchange rate corresponds to a depreciation (appreciation).

Figure 7. Actual and equilibrium real effective exchange rates within the euro area (continued) 

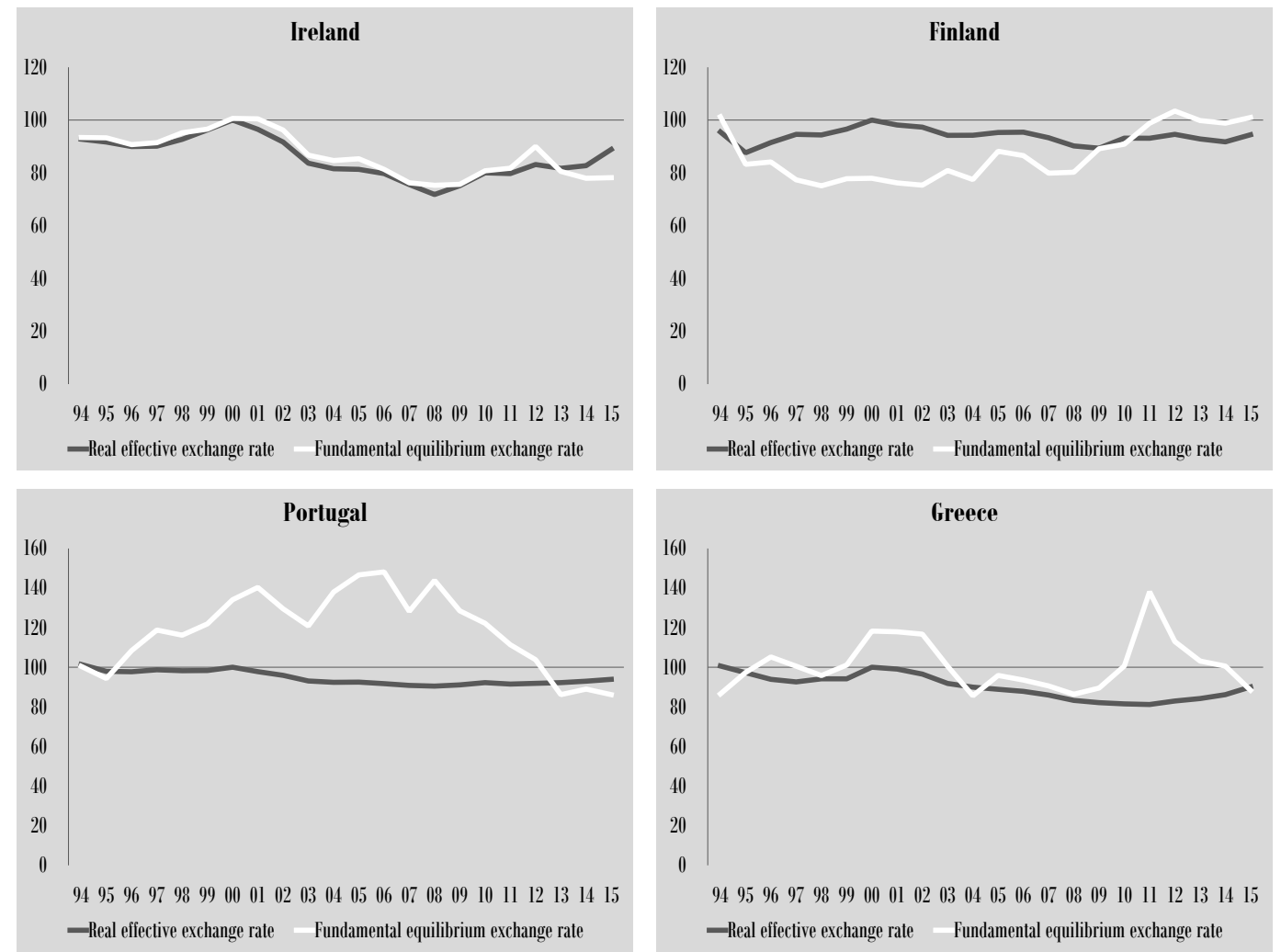

Source: author's calculations for the FEER and BIS for real effective exchange rates, basis 100 in 2000. Note: an increase (decrease) of the real effective exchange rate corresponds to a depreciation (appreciation).

Figure 8. Actual and equilibrium real effective exchange rates within the euro area (continued) 

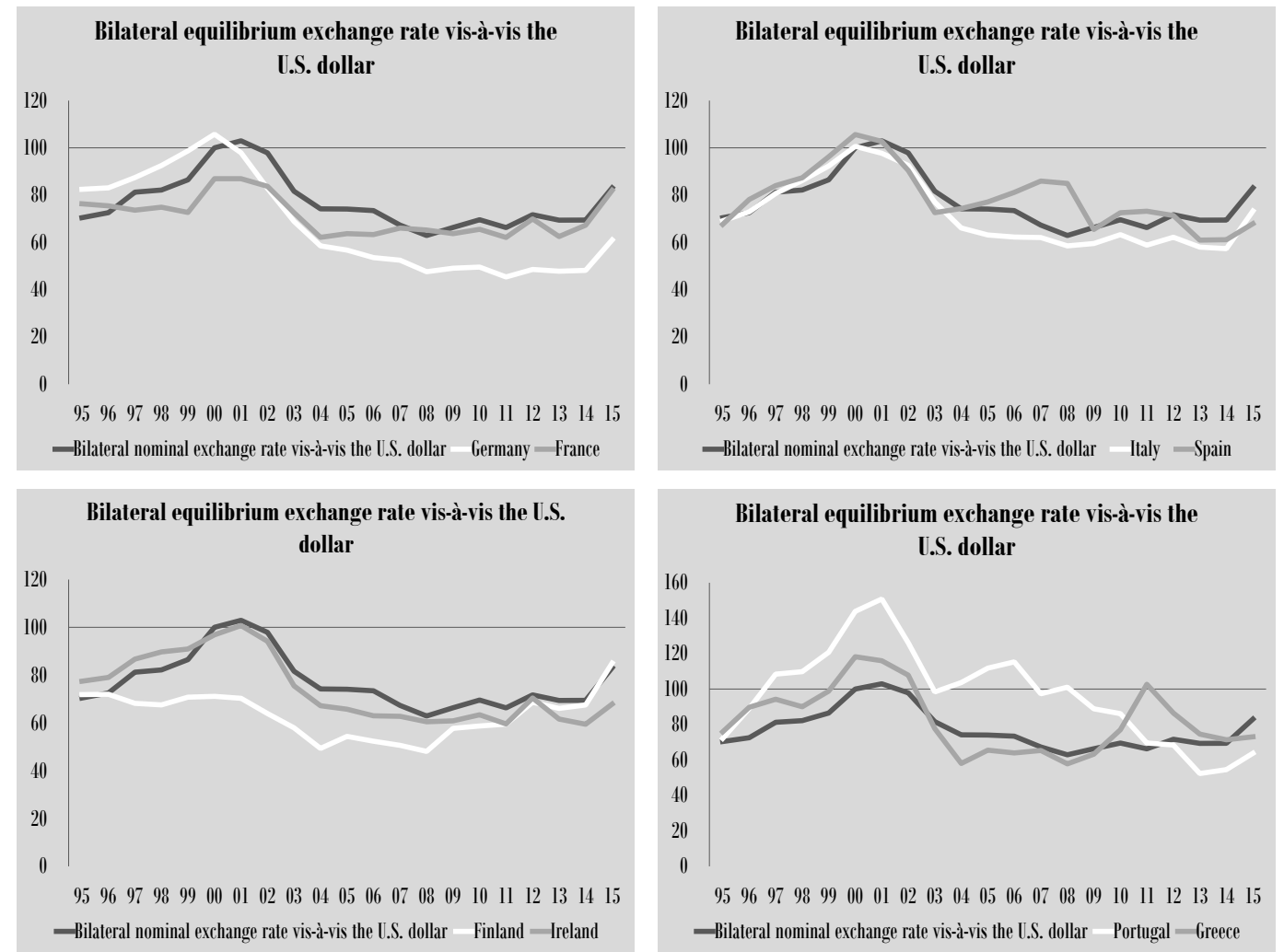

Source: author's calculations for the bilateral FEER and OECD for bilateral exchange rates, basis 100 in 2000. Note: an increase (decrease) of the bilateral nominal exchange rate corresponds to a depreciation (appreciation).

Figure 9. Actual and equilibrium bilateral nominal exchange rates within the euro area 
2015) and by largely positive relative output gaps as shown in figure 4 . The other main core economy of the euro area, France, seems to be in a more balanced position than a few years ago since its current account gap and its relative output gap have been virtually closed.

\section{Conclusion}

From the onset of the euro crisis to the Brexit vote, we have observed impressive reductions of current account imbalances in some peripheral countries of the euro area. These reductions can be the result of either a compression of internal demand or an improvement in external competitiveness. The aim of this study was to investigate whether exchange rate misalignments have been reduced in these economies. Indeed, a reduction of exchange rate misalignments can partly reflect an improvement in external competitiveness.

In order to answer this crucial question, we include the correction of Tamim Bayoumi and Hamid Faruqee (Isard and Faruqee, 1998) in the FEER methodology of Jeong et al. (2010a). This correction allows us to control for the reduced synchronization of business cycles in the euro area underlined by Campos and Macchiarelli (2016). To overcome the over-determination problem, our FEER methodology ensures symmetric treatment for each trading partner since we follow the SMIM proposed by Cline (2008). Besides, our two-step analysis seems to be particularly fitted to derive exchange rate misalignments for the euro and/or within the monetary union.

In a global perspective, one of the most striking features of the results is that the euro has been largely undervalued in recent years. This result can be simply explained by the fact that overvaluations have been reduced in several peripheral countries and that undervaluations have been fairly stable in some core countries. Quite remarkably, the Chinese yuan and the U.S. dollar do not seem to experience any exchange rate misalignment. Finally, the pound sterling has been largely overvalued. This last evolution reflects a growing divergence amongst European economies.

In the euro area, the results indicate that exchange rate misalignments have been reduced in Italy, Spain, Portugal and to a lesser extent in Greece. These reductions show that these countries have managed to improve their external competitiveness even after controlling for business cycles synchronization. However, these improvements could only be temporary. Indeed, as we can observe for the Irish economy, the country has to be very open to external trade in order to reap the possible benefits of internal devaluation in the long run.

Ultimately, these improvements in external competitiveness obtained via internal devaluations can be preserved only if countries manage to improve their non-price competitiveness (i.e. the quality of the exported goods and services), their trade openness, and their international specialization in the long run. It seems quite clear that these evolutions will not be achieved in the short-to-medium run. Indeed, the growing divergence of economic structures between Member States implies that we need to reject a "one size fits all" approach in designing economic policies aimed at improving external competitiveness within the euro area. 


\section{References}

Bergsten, F. (2010). We can fight fire with fire on the renminbi. Financial Times.

Blanchard, O. and Milesi-Ferretti, G. M. (2012). (Why) Should current account balances be reduced? IMF Economic Review, 60(1):139-150.

Borowski, D. and Couharde, C. (2003). The exchange rate macroeconomic balance approach: New methodology and results for the euro, the dollar, the yen and the pound sterling. Open Economies Review, 14(2):169-190.

Campos, N. F. and Macchiarelli, C. (2016). Core and periphery in the European monetary union: Bayoumi and Eichengreen 25 years later. Economic Letters, 147:127-130.

Carton, B. and Hervé, K. (2012). Estimation of consistent multi-country FEERs. Economic Modelling, 29:1205-1214.

Cline, W. R. (2008). Estimating consistent fundamental equilibrium exchange rates. Working paper 08-6, Peterson Institute for International Economics.

Coudert, V., Couharde, C., and Mignon, V. (2013). On Currency Misalignments within the Euro Area. Review of International Economics, 21(1):35-48.

Driver, R. L. and Westaway, P. F. (2005). Concepts of equilibrium exchange rates. Working paper 248, Bank of England.

Isard, P. and Faruqee, H. (1998). Exchange Rate Assessment: Extension of the Macroeconomic Balance Approach. Occasional paper 167, International Monetary Fund.

Jeong, S.-E. and Mazier, J. (2003). Exchange rate regimes and equilibrium exchange rates in East Asia. Revue économique, 54(5):1161-1182.

Jeong, S.-E., Mazier, J., and Saadaoui, J. (2010a). Exchange rate misalignments at world and European levels: A FEER approach. International Economics, 121(3):25-58.

Jeong, S.-E., Mazier, J., and Saadaoui, J. (2010b). Exchange rate misalignments at world and European levels: A FEER approach. Working paper 2010-03, Center for Economics of Paris North.

Lee, J., Milesi-Ferretti, G. M., Ostry, J. D., Prati, A., and Ricci, L. A. (2008). Exchange rate assessments: CGER methodologies. Occasional paper 261, International Monetary Fund.

López-Villavicencio, A., Mazier, J., and Saadaoui, J. (2012). Temporal dimension and equilibrium exchange rate: A FEER / BEER comparison. Emerging Markets Review, 13(1):58-77.

Pain, N., Mourougane, A., Sédillot, F., and Le Fouler, L. (2005). The new OECD international trade model. Working paper 440, The Organisation for Economic Co-operation and Development.

Saadaoui, J. (2011). Exchange rate dynamics and fundamental equilibrium exchange rates. Economics Bulletin, 31(3):1993-2005.

Saadaoui, J. (2015a). Does financial openness explain the increase of global imbalances before the crisis of 2008? International Economics, 143:23-35.

Saadaoui, J. (2015b). Global imbalances: Should we use fundamental equilibrium exchange rates? Economic Modelling, 47(C):383-398.

Saadaoui, J., Mazier, J., and Aflouk, N. (2013). On the determinants of exchange rate misalignments. Applied Economics Letters, 20(18):1608-1610.

Tridico, P. and Fadda, S. (2015). The Economic Crisis in Social and Institutional Context: Theories, Policies and Exit Strategies. Routledge Chapman Hall.

Williamson, J. (1983). The Exchange Rate System. Institute for International Economics.

Williamson, J. (1994). Estimating Equilibrium Exchange Rates. Peterson Institute Press. Peterson Institute for International Economics. 


\section{Acknowledgement(s)}

I would like to thank the organizers and the participants of the $3^{\text {rd }}$ International Workshop on Financial Markets and Non-linear Dynamics for their useful remarks. This paper has also benefited from relevant comments made by the participants of the OFCE internal seminar that took place in June 2017. The author is grateful to Katharina Priedl for her invaluable help with proofreading and editing. All remaining errors and omissions are mine. 


\section{Appendix A. The multinational trade model in logarithmic differential}

In order to compute the exchange rate misalignment directly, the equations of the multinational model are written in logarithmic differential. Thus, variables in lower case will correspond to logarithmic differences $\left(x=\frac{d X}{X}=\frac{X-X^{e}}{X^{e}}\right)^{16}$ :

$$
\begin{gathered}
x_{i}=\eta x_{i} \sum_{j \neq i} \alpha_{i j} m_{j}+\varepsilon x_{i}\left(p m x_{i}-p x_{i}\right) \\
p m x_{i}=\sum_{j \neq i} \lambda_{i j}\left(p x_{j}-e_{j}\right)+e_{i} \\
m_{i}=\eta m_{i} d i_{i}+\varepsilon m_{i}\left(p d_{i}-p m_{i}\right) \\
p m m_{i}=\sum_{j \neq i} \mu_{i j}\left(p x_{j}-e_{j}\right)+e_{i} \\
\sum_{i} v x_{i}\left(x_{i}+p x_{i}-e_{i}\right)=\sum_{i} v m_{i}\left(m_{i}+p m_{i}-e_{i}\right) \\
\sum_{i} w x_{i} x_{i}=\sum_{i} w m_{i} m_{i} \\
p x_{i}=\alpha x_{i} p m x_{i}+\left(1-\alpha x_{i}\right) p_{i} \\
p d_{i}=a_{i} p m_{i}+\left(1-a_{i}\right) p_{i} \\
p m_{i}=\alpha m_{i} p m m_{i}+\left(1-\alpha m_{i}\right) p d_{i} \\
b_{i}\left(1-\sigma_{p e t x_{i}}-\sigma_{x_{i}}\right)\left(p x_{i}+x_{i}-p m_{i}-m_{i}\right)
\end{gathered}
$$

Where $w x, w m, v x$ and $v m$, represent the share of each economy in the world exports in volume, the world imports in volume, the world exports in value and the world imports in value, respectively; $T=P X X / P M M$, is the coverage ratio; $\mu=P M M / P Y$, is the openness ratio; $i$, is the interest rate for external debt; $F$, the net external debt; $\sigma p e t x=E P_{p e t} M_{\text {pet }} / P X X$, is the ratio of net oil imports in value on non-oil exports in value and $\sigma x=i E F / P X X$, is the ratio of the foreign debt service on non-oil exports in value.

${ }^{16}$ For the sake of clarity, we define the following trade weights: $\lambda_{i j}=\frac{X_{i \rightarrow j}}{X_{i}} ; \mu_{i j}=\frac{M_{i \leftarrow j}}{M_{i}} ; \alpha_{i j}=\frac{X_{i \rightarrow j}}{M_{j}} ; \nu_{i j}=$ $\left(\frac{X_{i \rightarrow j}+M_{i \leftarrow j}}{X_{i}+M_{i}}\right)$. 
For the purpose of clarity, we detail the derivation of the current account gap, $b$, presented in equation A7:

$$
\begin{gathered}
b_{i}=\left(\frac{B_{i}}{P_{i} Y_{i}}\right)-\left(\frac{B_{i}^{e}}{P_{i}^{e} Y_{i}^{e}}\right)=d\left(\frac{B_{i}}{P_{i} Y_{i}}\right)=\mu_{i} d\left(\frac{B_{i}}{P M_{i} M_{i}}\right) \\
b_{i}=\mu_{i} d\left[\left(\frac{P X_{i} X_{i}}{P M_{i} M_{i}}\right)\right] \\
-\mu_{i} d\left[1-\left(\frac{E P_{p e t} M_{p e t i}}{P X_{i} X_{i}}\right)\left(\frac{P X_{i} X_{i}}{P M_{i} M_{i}}\right)-\left(\frac{i_{i} E_{i} F_{i}}{P X_{i} X_{i}}\right)\left(\frac{P X_{i} X_{i}}{P M_{i} M_{i}}\right)\right] \\
b_{i}=\mu_{i} d T_{i}\left(1-\sigma_{\text {petxi }}-\sigma_{x i}\right)
\end{gathered}
$$




\section{Appendix B. The national trade model in logarithmic differential}

Same as for the multinational framework, the equations of the national model are written in logarithmic differential in order to compute the exchange rate misalignment directly. Again, variables in lower case will correspond to logarithmic differences $(x=$ $\left.\frac{d X}{X}=\frac{X-X^{e}}{X^{e}}\right)$ :

$$
\begin{gathered}
x_{i}=\eta x_{i} d_{i}^{*}+\left(1-\alpha x_{i}\right) \varepsilon x_{i} r_{i} \\
m_{i}=\eta m_{i} d i_{i}-\left(\alpha m_{i} \varepsilon m_{i}\right) r_{i} \\
p x_{i}=\alpha x_{i} r_{i}+p_{i} \\
p m_{i}=\alpha m_{i} r_{i}+p_{i} \\
b_{i}=\mu_{i} T_{i}\left(1-\sigma_{p e t x_{i}}-\sigma_{x_{i}}\right)\left(p x_{i}+x_{i}-p m_{i}-m_{i}\right)
\end{gathered}
$$

As previously mentioned in equation 17 , we can derive an exchange rate misalignment specific to each economy. Here, it can be expressed in real effective terms based on the GDP deflator:

$$
\begin{gathered}
\frac{d T_{i}}{T_{i}}=p x_{i}+x_{i}-p m_{i}-m_{i} \\
\frac{d T_{i}}{T_{i}}=\left(\eta x_{i} d_{i}^{*}-\eta m_{i} d i_{i}\right)+\left[\left(1-\alpha x_{i} \varepsilon x_{i}\right)+\varepsilon m_{i} \alpha m_{i}+\alpha x_{i}-\alpha m_{i}\right] r_{i}
\end{gathered}
$$

From equations A10 and B5, we know that the current account gap can be expressed as follows:

$$
\begin{gathered}
b_{i}=\mu_{i} d T_{i}\left(1-\sigma_{\text {petxi }}-\sigma_{x_{i}}\right) \\
\frac{d T_{i}}{T_{i}}=\frac{b_{i}}{\mu_{i} T_{i}\left(1-\sigma_{p e t x_{i}}-\sigma_{x_{i}}\right)}
\end{gathered}
$$

As in equation 17, we find the expression of the exchange rate misalignment specific to each economy expressed in real effective terms based on the GDP deflator: 


$$
r_{i}=\left[\frac{\left(\left(b_{i} / \mu_{i} T_{i}\left(1-\sigma_{p e t x_{i}}-\sigma_{x_{i}}\right)\right)+\eta m_{i} d i_{i}-\eta x_{i} d_{i}^{*}\right)}{\left(\left(1-\alpha x_{i}\right) \varepsilon x_{i}+\varepsilon m_{i} \alpha m_{i}+\alpha x_{i}-\alpha m_{i}\right)}\right]
$$

Thanks to the equation 15, we can derive the expression for the exchange rate misalignment in bilateral nominal terms vis-à-vis the U.S. dollar:

$$
r_{i}=e_{i}+p x_{i}^{*}-p_{i}
$$

For the sake of simplicity, we assume that internal prices are in equilibrium, thus $p_{i}=\frac{\left(P_{i}-P_{i}^{e}\right)}{P_{i}^{e}}=0$. As in equation 19, the exchange rate misalignment in bilateral nominal terms vis-à-vis the U.S. dollar is expressed as follows:

$$
e_{i}=r_{i}-\sum_{j \neq i} \lambda_{i j}\left(p x_{j}-e_{j}\right)
$$

Thanks to the OCI solution of the multinational model, we can derive the exchange rate misalignment in real effective terms based on consumer prices, $P D$ :

$$
\begin{gathered}
R C_{i}=\frac{E_{i} P D_{i}^{*}}{P D_{i}} \\
r c_{i}=e_{i}+p d_{i}^{*}-p d_{i} \\
p d_{i}^{*}=\sum_{j \neq i} \nu_{i j}\left(p d_{j}-e_{j}\right) \\
p d_{i}=\mu_{i} p m_{i}+\left(1-\mu_{i}\right) p_{i} \\
p m_{i}=\alpha m_{i}\left(e_{i}+p m_{i}^{*}\right)+\left(1-\alpha m_{i}\right) p_{i} \\
p d_{i}=\alpha m_{i} \mu_{i}\left(e_{i}+p m_{i}^{*}\right) \\
r c_{i}=\left(1-\alpha m_{i} \mu_{i}\right) r_{i}+p d_{i}^{*}-p x_{i}^{*}
\end{gathered}
$$


As in equation 18, we can derive the exchange rate misalignment expressed in real effective terms based on consumer prices. We note that the variables $p d_{j}, e_{j}$ and $p x_{j}$ are retrieved from the OCI resolution of the multinational model:

$$
r c_{i}=\left(1-\alpha m_{i} \mu_{i}\right) r_{i}+\sum_{j \neq i} \nu_{i j}\left(p d_{j}-e_{j}\right)-\sum_{j \neq i} \lambda_{i j}\left(p x_{j}-e_{j}\right)
$$




\section{Appendix C. Current account gaps in the multinational trade model}
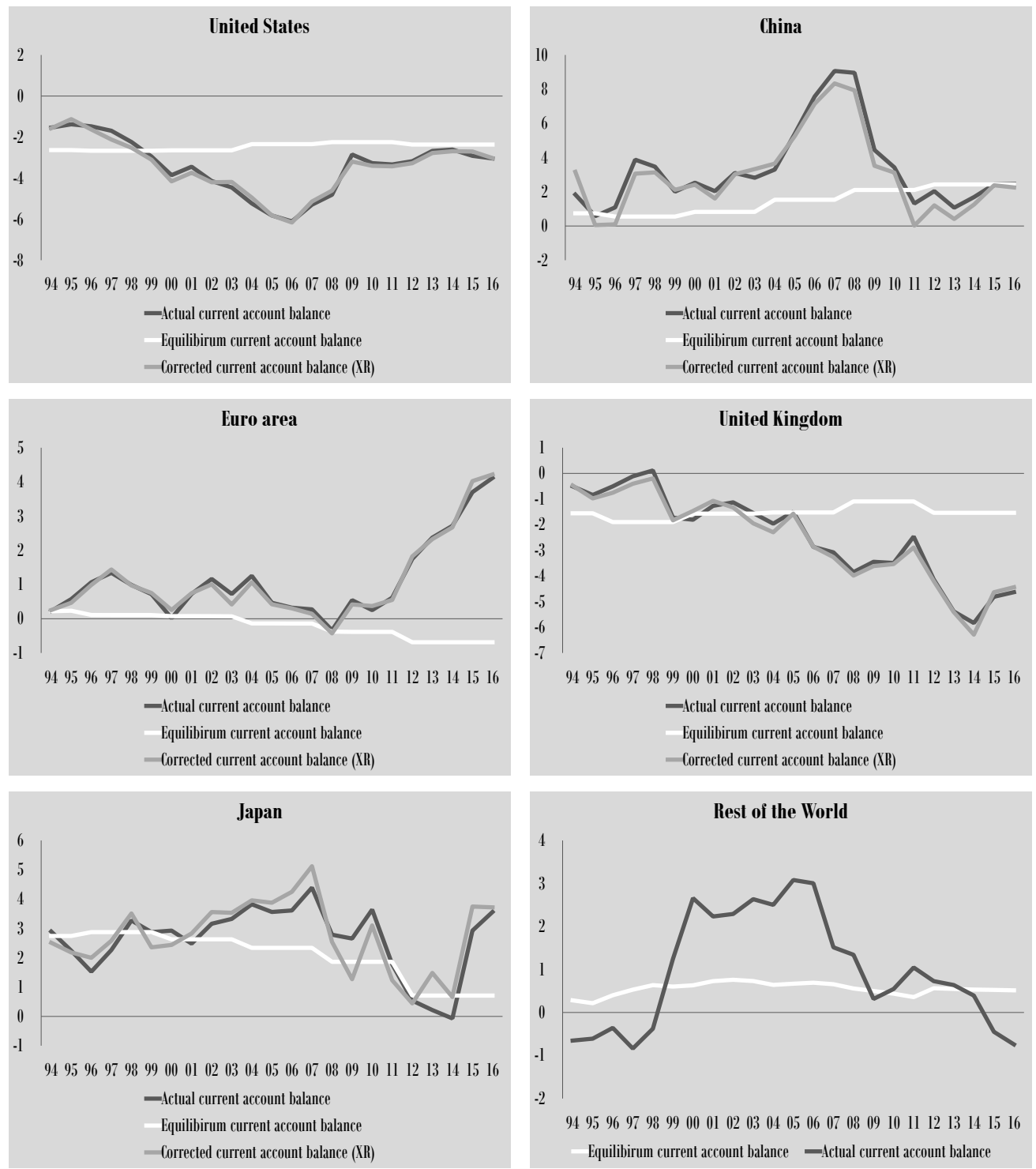

Source: author's estimates for the equilibrium current account balance and IMF's World Economic Outlook (April 2016) for the current account balance. Note: The global discrepancy is corrected proportionately to the share in the world trade ensuring the current account balances offset each other at the global level.

Figure C1. Current account gaps 